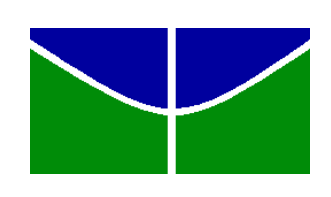

$$
\begin{gathered}
\text { UNIVERSIDADE DE BRASÍLIA } \\
\text { INSTITUTO DE CIÊNCIAS HUMANAS } \\
\text { DEPARTAMENTO DE SERVIÇO SOCIAL }
\end{gathered}
$$

TRABALHO DE CONCLUSÃO DE CURSO DE GRADUAÇÃO

CLARICE BARBOSA VIEIRA

\title{
A questão racial e a cultura afro-brasileira \\ Um estudo acerca dos livros didáticos
}

Orientadora: Silvia Cristina Yannoulas 
CLARICE BARBOSA VIEIRA

\section{A questão racial e cultura afro-brasileira \\ Um estudo acerca dos livros didáticos}

Trabalho de Conclusão de Curso apresentado ao Departamento de Serviço Social do Instituto de Ciências Humanas da Universidade de Brasília como requisito parcial para a obtenção do grau de Assistente Social.

Orientadora: Professora Dra. Silvia Cristina Yannoulas 


\section{A questão racial e cultura afro-brasileira

\author{
Um estudo acerca dos livros didáticos
}

Trabalho de Conclusão de Curso apresentado ao Departamento de Serviço Social do Instituto de Ciências Humanas da Universidade de Brasília como requisito parcial para a obtenção do grau de Assistente Social.

BANCA EXAMINADORA

Professora Doutora Silvia Cristina Yannoulas - SER/Universidade de Brasília

Professor Doutor Mário Ângelo Silva - SER/Universidade de Brasília

Mestra em Educação Danielle Oliveira Valverde - ONU Mulheres 
Dedico este trabalho:

aos meus pais, Tannia e Emanuel;

aos meus amigos;

ao meu namorado, Raffael. 


\section{AGRADECIMENTOS}

Agradeço primeiramente a toda força divina que me dá paz de espírito e que pela qual sou protegida.

Aos meus pais, em especial minha mãe, Tannia, por todo o apoio e dedicação que recebi nesses longos anos de graduação e pela presença que se fez necessária para meu crescimento intelectual e humano.

A todos que contribuíram para a execução deste trabalho; Em especial a professora Silvia Cristina Yannoulas pela competência ímpar em conduzir meu trabalho de conclusão de curso e me mostrar importantes caminhos para chegar ao fim desta jornada.

À professora Denise Botelho, pela orientação e atenção nos momentos de impasse à pesquisa de campo. Ainda assim, pelas críticas que me fizeram refletir sobre a importância desta pesquisa para a abordagem étnico-racial no campo do Serviço Social.

À professora Francis Luli, que aceitou em me conceder as obras didáticas necessárias para o desenvolvimento de minha pesquisa.

Ao meu padrinho Paulão e minha madrinha Lídia que acompanharam meu crescimento e me deram exemplos de vida.

Ao meu namorado, Raffael, pelo humanismo e companheirismo únicos, e por estar ao meu lado nas dúvidas e nas certezas que no fim da graduação se mostraram um pouco mais árduas.

A minha família em geral por acompanhar esta minha trajetória desde que conquistei minha vaga na Universidade de Brasília.

A todos meus amigos e colegas de Universidade, em especial os meus amigos do curso de Serviço Social, em especial Marina, por compartilhar momentos difíceis que tive tanto na Universidade como fora dela, por demonstrar tamanha amizade e carinho em todos os espaços da minha vida.

A todos os professores e funcionários do Departamento de Serviço Social da Universidade de Brasília pelo auxílio fornecido sempre que necessário.

Obrigada... 
"A educação é a arma mais poderosa que você pode usar para mudar o mundo"

\section{Nelson Mandela}

"Enquanto eu tiver perguntas e não houver respostas... Continuarei a escrever."

Clarice Lispector 


\section{RESUMO}

Desde a sanção da Lei n 10.639 de janeiro de 2003 é obrigatório o estudo da história e da cultura afro-brasileira no ensino fundamental e no ensino médio das escolas brasileiras públicas e privadas. A escolha da matriz qualitativa como método de pesquisa teve como pressuposto identificar a abordagem da questão racial e da cultura afro-brasileira nos livros didáticos aprovados pelo Ministério da Educação (MEC) e utilizados nas escolas públicas de ensino fundamental do DF. A hipótese de que os livros didáticos ainda não colaboram de forma efetiva para a desconstrução da discriminação racial dentro do espaço escolar foi norteada pela pesquisa documental. Para tanto, foram escolhidos quatro livros didáticos de história trabalhados no âmbito do ensino fundamental do Distrito Federal: Projeto Pitanguá, autoria de Maria Raquel Apolinário Melani, editora Moderna, edição de 2008 ( $5^{\circ}$ ano); Descobrindo a história, autoria de Sônia Mozer e Vera Telles, editora Ática, edição de 2007 (6 ${ }^{\mathrm{a}}$ série); Saber e fazer história, autoria de Gilberto Cotrim, editora Saraiva, edição de 2006 ( $7^{\mathrm{a}}$ série) e Construindo consciências, autoria de Leonel Itaussu de A, Mello \& Luís César Amad Costa, editora Scipione, edição de 2008 ( $8^{\text {a }}$ série). Esta pesquisa buscou identificar a contribuição do conteúdo de história e cultura africana contido nos livros didáticos para a propagação da diversidade humana no espaço escolar a partir da promulgação da Lei 10.639/03 e da legislação correlata tais como a Constituição Federal de 1988, o parecer n ${ }^{\circ} 3$ e a resolução $n^{\circ} 1$ de 2004 do Conselho Nacional de Educação sobre a implementação da referida legislação. A abordagem qualitativa utilizada pela realização de duas entrevistas semi-estruturadas com ativistas do movimento negro e pesquisadoras da Secretaria de Educação Continuada, Alfabetização e Diversidade (SECAD) e da Escola de Aperfeiçoamento dos Profissionais da Educação (EAPE). Os resultados de pesquisa demonstraram que apesar dos avanços terem sido significativos após a sanção da Lei 10.639/03, o campo teórico voltado para a temática racial ainda é carente de imagens e significados positivos do negro no decorrer da história brasileira, principalmente no período escravocrata.

Palavras-chave:

Lei 10.639/03, história e cultura afro-brasileira, livro didático, discriminação racial. 


\section{SUMÁRIO}

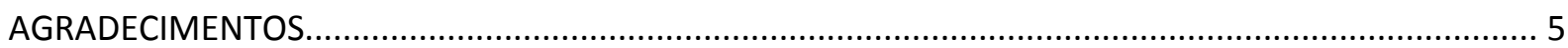

RESUMO

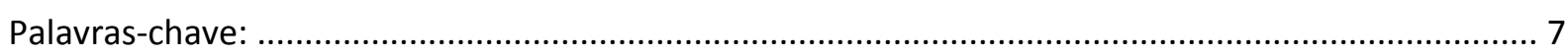

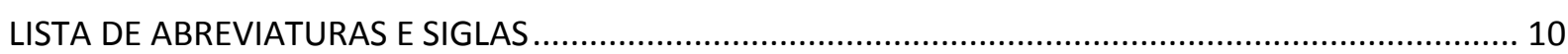

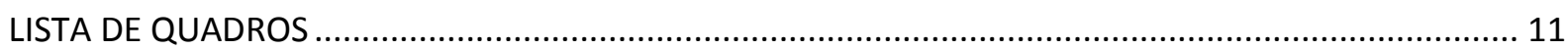

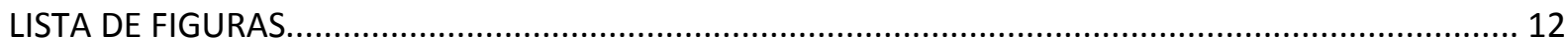

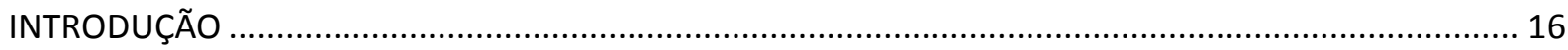

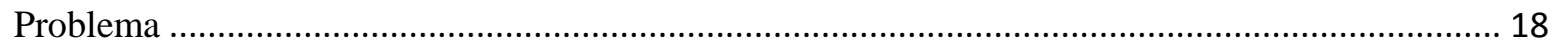

Hipótese

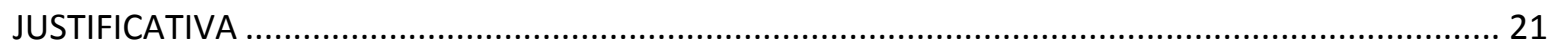

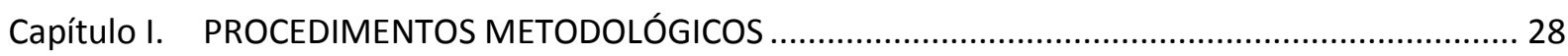

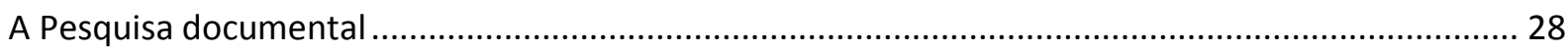

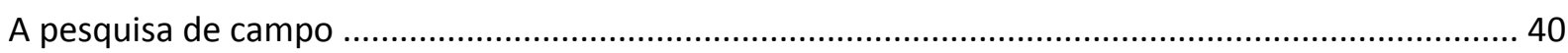

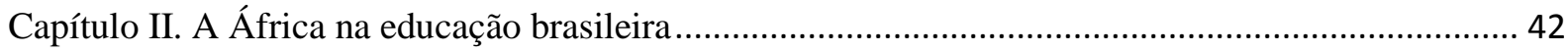

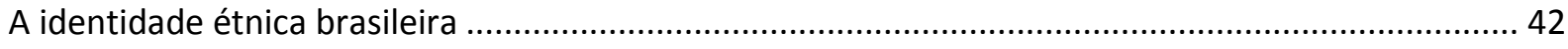

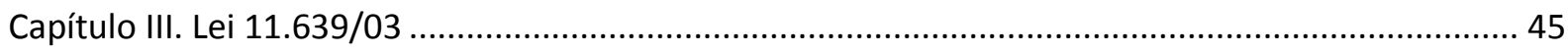

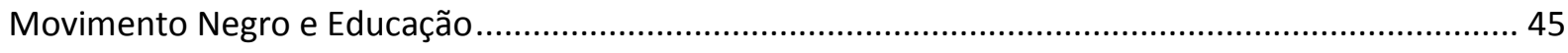

As opiniões dos entrevistados sobre o Movimento Negro na Educação............................................ 45

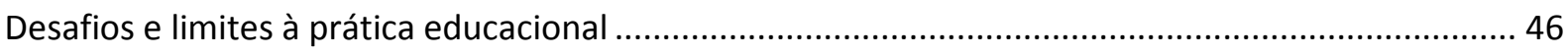

As opiniões das entrevistadas sobre o papel institucional para a propagação da questão racial nas

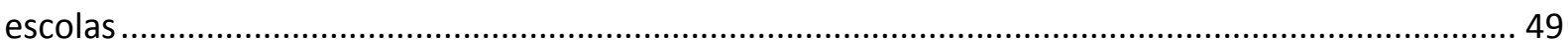

As opiniões das entrevistadas sobre a legislação e o livro didático.................................................... 50

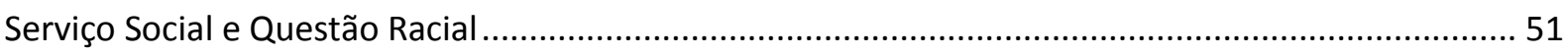

A opinião das entrevistadas sobre a visibilidade do negro na sociedade brasileira ............................. 53

Capítulo IV: A história da África nos livros didáticos: descrição e análise de dados ............................ 55 


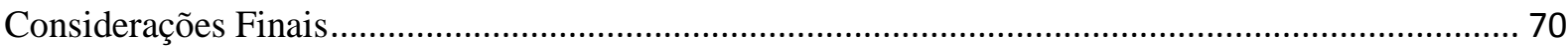

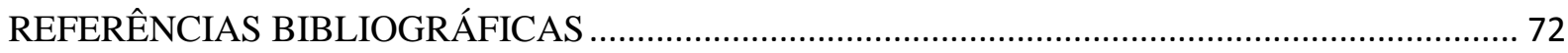

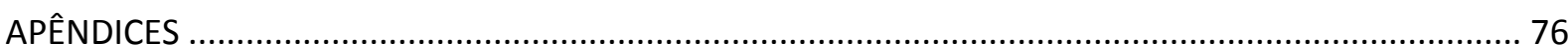

APÊNDICE I: ROTEIRO DE ENTREVISTA SEMI-ESTRUTURADA _........................................................ 76

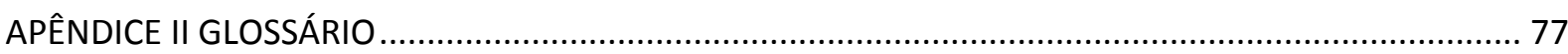

APÊNDICE III: REFERÊNCIAS AO NEGRO NOS LIVROS DIDÁTICOS .................................................... 79

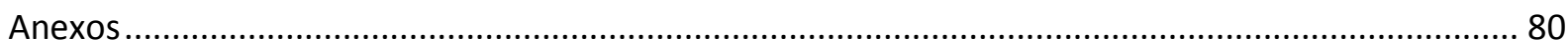

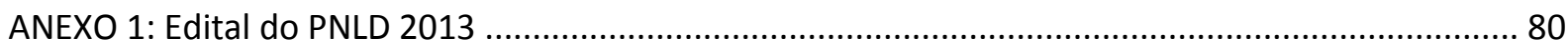




\section{LISTA DE ABREVIATURAS E SIGLAS}

AIDS - Acquired Immunodeficiency Syndrome

CLAM/IMS/UERJ - Centro Latino-Americano em sexualidade e direitos humanos da Universidade Estadual do Rio de Janeiro

CNE - Conselho Nacional de Educação

CP - Conselho Pleno

DOU - Diário Oficial da União

EAPE - Escola de Aperfeiçoamento dos Profissionais da Educação

FNB - Frente Negra Brasileira

FNDE - Fundo Nacional de Desenvolvimento de Educação

GERAJU - Grupo de pesquisa em Educação e Políticas Públicas: gênero, raça/etnia e juventude

GTEC/CBL - Gerência de Tecnologias e Coordenação de Acervo Bibliográfico e livros didáticos

LDB - Lei de Diretrizes e Bases da Educação Nacional

MEC - Ministério da Educação

MNU - Movimento Negro Unificado

PNLA - Programa Nacional do Livro Didático para a Alfabetização de Jovens e Adultos

PNLD - Programa Nacional de Livros Didáticos

PNLEM - Programa Nacional do Livro Didático para o Ensino Médio

TCC - Trabalho de Conclusão de Curso

TCLE - Termo de Consentimento Livre e Esclarecido

SECAD - Secretaria de Educação Continuada, Alfabetização e Diversidade

SEE/DF - Secretaria de Estado da Educação do Distrito Federal

SEPPIR - Secretaria de Políticas de Promoção da Igualdade Racial

SIA - Setor de Indústria e Abastecimento

WWW - World Wide Web 


\section{LISTA DE QUADROS}

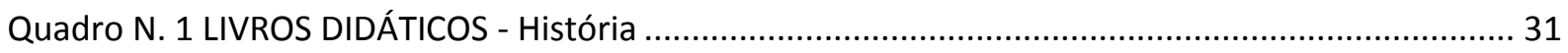

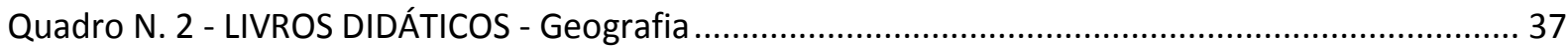




\section{LISTA DE FIGURAS}

Figura 1 - "Negros lavando diamantes no Rio Jequitinhonha em Serro Frio, gravura de John Mawe, de

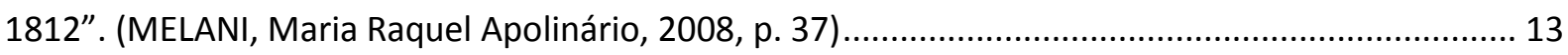

Figura 2 - Ilustração das atividades extras do livro didático. (MELANI, Maria Raquel Apolinário, 2008, p. 93)

Figura 3 - "Abolicionista José do Patrocínio subindo a um pedestal construído pelos negros. Publicada na Revista Illustrada em outubro de 1888".(MOZER, Sônia \& TELLES, Vera, p. 131) 13

Figura 4 - "Três orixás, pintura a óleo de Djanira Motta e Silva, 1966". (MOZER, Sônia \& TELLES, Vera, p. 109)

Figura 5 - "Menino de família rica ao lado de sua ama-de-leite em foto de 1860 . Por essa época, as amas-de-leite eram geralmente escravas. Não raro elas desenvolviam com as crianças que amamentavam uma relação doce e afetuosa". (MOZER, Sônia \& TELLES, Vera, p. 112) ......

Figura 6 - "Montado em um cavalo branco, capataz fiscaliza a colheita de café por um grupo de escravos na fazenda Santana, em Juiz de Fora, Minas Gerais, 1869". (MOZER, Sônia \& TELLES, Vera, p. 109)

Figura 7 - "Escravos acorrentados uns aos outros para evitar fuga uma das provas do alto controle dos senhores". (COTRIM, Gilberto, 2006, p. 156)

Figura 8 - "O marinheiro João Cândido, à direito, líder da Revolta da Chibata. Foto de 1910". (MELLO, Leonel Itaussu de A. \& COSTA, Luis César Amad, 2008, p. 63)

Figura 9 - "A descolonização da Ásia e da África (1945-1975)". (MELLO, Leonel Itaussu de A. \& COSTA, Luis César Amad, 2008, p. 148) 


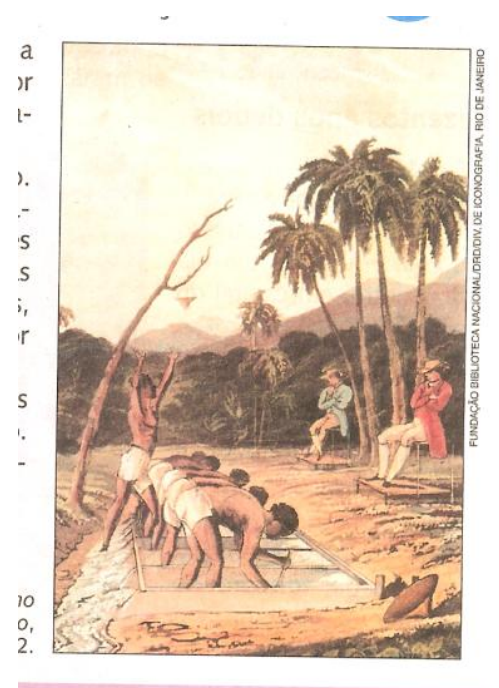

Figura 1

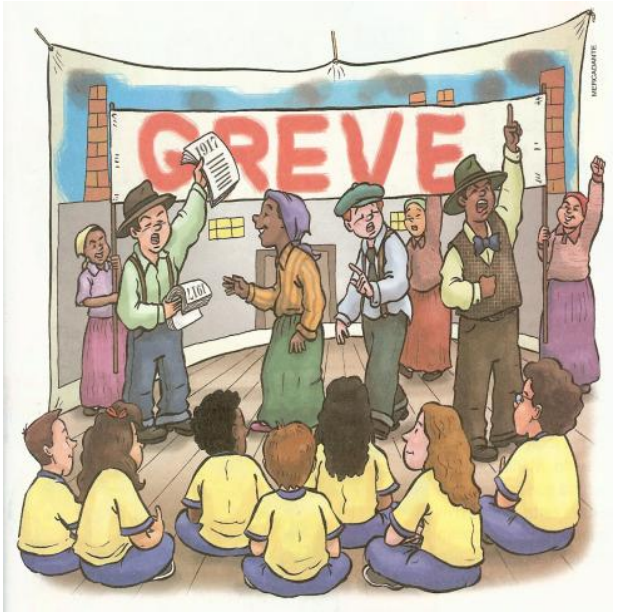

Figura 2

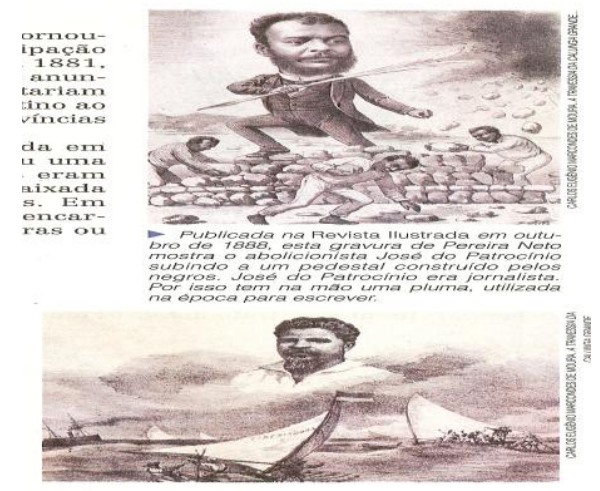

Figura 3 


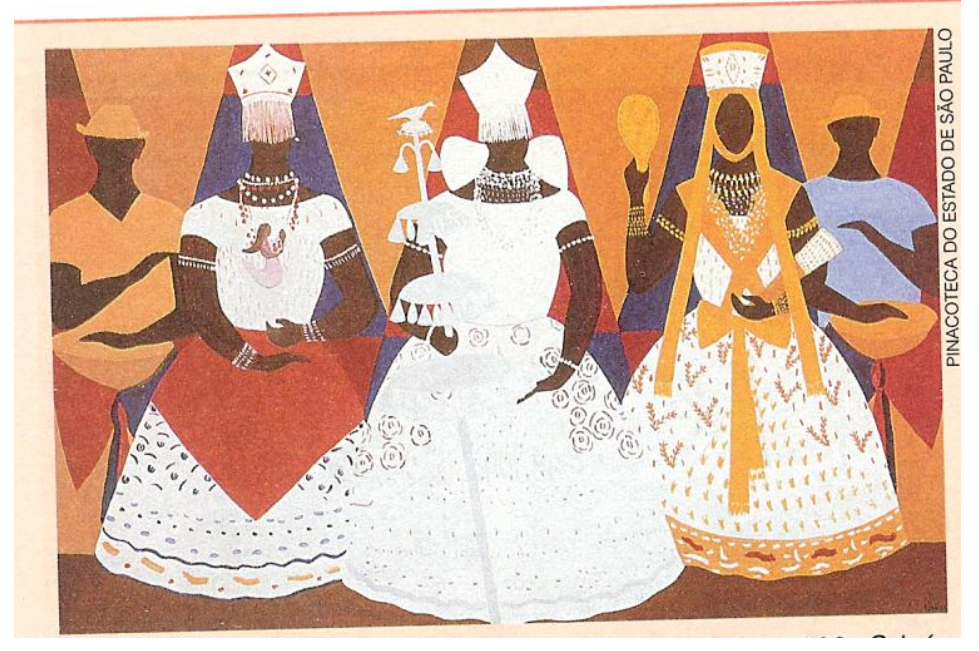

Figura 4

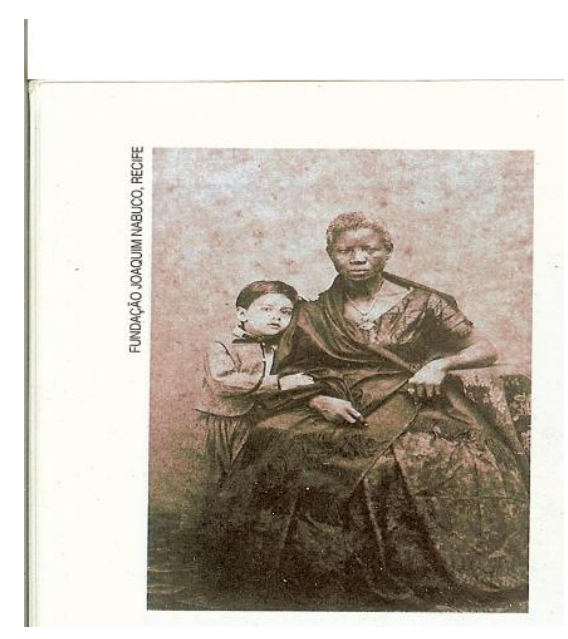

Figura 5

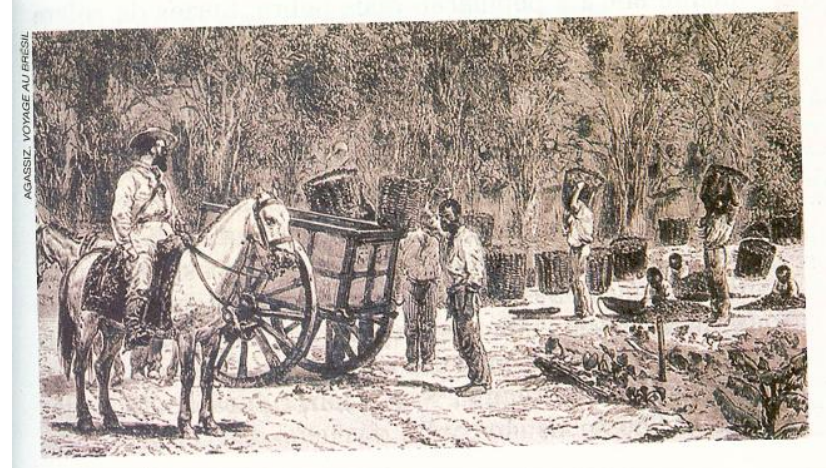

Figura 6 


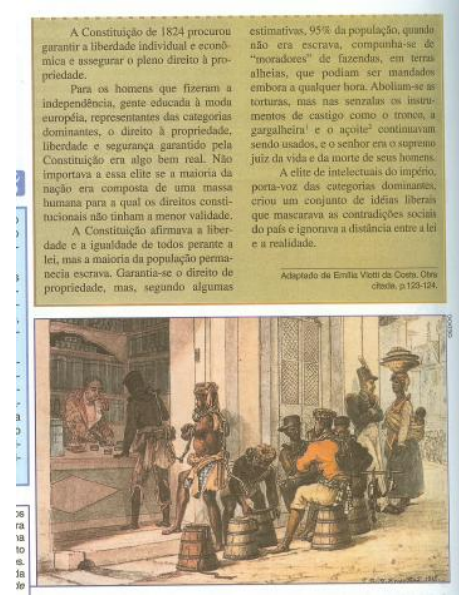

Figura 7

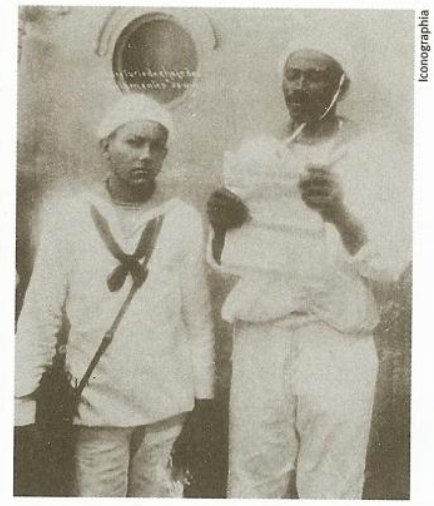

(1) 0 marinheiro João Cândido, à direita, líder da Revolta da Chibata. Foto de 1910.

Figura 8

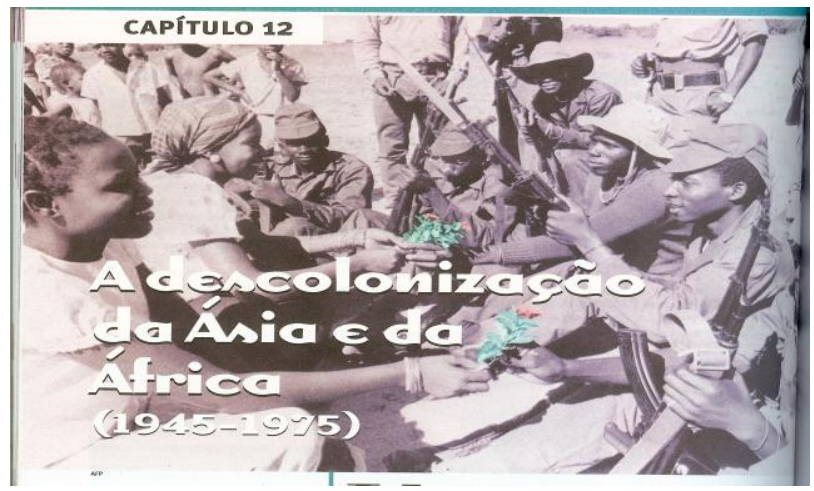

Figura 9 


\section{INTRODUÇÃo}

Este Trabalho de Conclusão de Curso (TCC) propõe a problemática do racismo nos livros didáticos a partir da sanção da Lei 10.639/03. A amplitude da temática racial na sociedade brasileira reflete uma variedade de questionamentos que não poderiam ser tratados em sua totalidade por um único estudo acadêmico. Ainda que a relevância de todo o contexto sócio-histórico perpetue transformações nas relações sociais em suas diversas dinâmicas, deve-se considerar a pontualidade de cada investigação social para a compreensão didática da realidade como um todo.

Sendo assim, e tendo como meta a elaboração de um TCC em Serviço Social, a pesquisa realizada centrou-se na questão racial abordada nos livros didáticos de história no ensino fundamental das escolas públicas do Distrito Federal.

As perspectivas de raça ${ }^{1}$ que a sociedade criou foram impulsionadas pelas teorias racistas do século XIX, as quais determinavam a superioridade de certos grupos (brancos) em relação a outros (não brancos) baseados em características biológicas e comportamentais. Tal cultura hierárquica faz com que a população negra enfrente inúmeras dificuldades em escapar do perfil sócio-econômico de pobreza e miséria deste país.

Reproduzimos padrões de classe, gênero e raça perpetuados desde os processos de colonização no Brasil, desde o processo de povoamento, exploração e dominação realizada pelos europeus a partir do século XVI nas atuais terras brasileiras. Se durante a escravidão os negros eram considerados "os de baixo", continuam hoje na mesma posição. A inferioridade estabelecida a partir de costumes diferentes e da "condição natural de escravos" passa hoje a ser definida a partir da cor. A linha de cor passou a se confundir com a linha de posição, de classe. Em outras palavras, a maioria dos negros passou a ocupar as mais baixas posições sociais da sociedade.

A escola, como um dos espaços institucionais da sociedade, reproduz valores, símbolos culturais, costumes que estão diretamente envolvidos com a dinâmica das relações

\footnotetext{
$1 \quad$ Adota-se nesse estudo um conceito de raça que se baseia naquele discutido por Guimarães (2002), qual seja, o de que não existe raça do ponto de vista biológico, mas há um conceito social descrito como uma categoria política de resistência ao racismo, mas também uma categoria analítica que permite desvendar que as discriminações e desigualdades existentes são efetivamente raciais, e não, simplesmente, classistas. Ela é útil nas análises de orientações de ação que são realizadas pela idéia de raça. $\mathrm{O}$ autor discorre que adotar uma postura anti-racialista, ou seja, não conceber a raça como categoria social não é garantia de ser anti-racista. (VALVERDE, 2008)
} 
sociais. Um assunto relevante nos dias atuais, mas ainda não compreendido em suas facetas de discriminação - o bullying -, se trata da manifestação de violência moral, física e psicológica contra um determinado grupo de estudantes. Essas facetas representam o racismo, a homofobia, a falta de discussão da sexualidade nas escolas. O espaço familiar muitas vezes é o primeiro alvo desses atos agressivos, sendo a escola um refúgio de consonância com essas práticas disfarçadas de brincadeiras.

Consideramos que no âmbito escolar há uma gama de possibilidades tanto de preservação como de desconstrução dessas difamações, definidas a partir do entendimento de função social deste espaço e da compreensão da ordem social desejada.

$\mathrm{Na}$ prática educacional, e em especial no cotidiano escolar, a linguagem que utilizamos está marcada por expressões que, às vezes, inconscientemente, contribuem para reforçar situações de preconceito, discriminação e racismo.

Estas práticas corroboram, portanto, para a manutenção de valores discriminatórios, que se perpetuam dentro e fora do ambiente escolar, como um ciclo sem fim. Cabe ressaltar que tais valores não somente se referem à discriminação racial. Além da convergência da discussão de gênero e raça em que a mulher negra se torna personagem central, tratamentos preconceituosos afetos às pessoas acima do peso, indígenas, homossexuais, pessoas com deficiência englobam alguns dos segmentos populacionais também excluídos da educação escolar brasileira.

Visto que a luta pelos direitos sociais tornou-se uma luta conjunta de todos os sujeitos, seria coerente o fortalecimento dos movimentos sociais para a concretude da dimensão real dos direitos humanos.

Até o ano de 2003 o Brasil não possuía nenhuma legislação específica que versasse sobre o tratamento da temática racial nas escolas. A Lei 10.639, de janeiro de 2003 passa a garantir a inclusão do conteúdo de história afro-brasileira nos currículos escolares de ensino fundamental e médio do país. No entanto, alguns estados e municípios brasileiros já legislavam sobre o tema em suas leis orgânicas, como os municípios de Salvador (1990), Belo Horizonte (1990), Porto Alegre (1991), Belém (1994), Aracaju (1994), São Paulo (1996), Teresina (1999) e Rio de Janeiro (1999). Essas conquistas locais foram resultados da mobilização dos movimentos negros articulados e com políticos que tratassem a questão racial como pauta central de governo.

No primeiro capítulo do TCC abordaremos os procedimentos de pesquisa realizados. No segundo capítulo mostraremos a relação da cultura africana com a educação brasileira. No 
terceiro capítulo esboçaremos a sanção da Lei $n^{\circ}$ 10.639/03 e seu diferencial para a política de educação, considerando o papel do assistente social para a efetivação desta política. Por último este trabalho colocará evidências da pesquisa documental deparadas nos livros didáticos de história do ensino fundamental.

Esta pesquisa situou-se no contexto das discussões acerca da implementação do ensino de história afro-brasileira. E teve como objetivo realizar análise em livros didáticos de ensino fundamental, editados após a vigência da Lei 10.639/2003. O estudo proposto sobre um dos mecanismos de implementação desta lei compreende a análise de alguns livros didáticos aprovados pelo Ministério da Educação (MEC) e distribuídos gratuitamente nas escolas públicas do Distrito Federal (DF), sendo utilizados no ensino fundamental compreendido do primeiro $\left(1^{\circ}\right)$ ao nono $\left(9^{\circ}\right)$ ano. Torna-se o critério principal de análise a inclusão de livros didáticos de livros didáticos de quinto $\left(5^{\circ}\right)$ ao nono $\left(9^{\circ}\right)$ ano, sendo que alguns livros analisados não têm a nova nomenclatura. Cabe ressaltar que os critérios não se detiveram especialmente ao espaço geográfico para a escolha do material analisado.

\section{Problema}

No caso da temática racial, modificações recentes na Legislação de Diretrizes e Bases da Educação Nacional - LDB (Lei no 9.394 de 20 de dezembro de 1996) acrescentaram ao texto original da LDB a obrigatoriedade do conteúdo de história e cultura afro-brasileira com a seguinte redação:

Art. 26-A. Nos estabelecimentos de ensino fundamental e de ensino médio, públicos e privados, torna-se obrigatório o estudo da história e cultura afro-brasileira e indígena. (Redação dada pela Lei no 11.645 , de 2008).

$\S 1^{\text {o }}$ O conteúdo programático a que se refere este artigo incluirá diversos aspectos da história e da cultura que caracterizam a formação da população brasileira, a partir desses dois grupos étnicos, tais como o estudo da história da África e dos africanos, a luta dos negros e dos povos indígenas no Brasil, a cultura negra e indígena brasileira e o negro e o índio na formação da sociedade nacional, resgatando as suas contribuições nas áreas social, econômica e política, pertinentes à história do Brasil. (Redação dada pela Lei n ${ }^{\circ} 11.645$, de 2008). 
$\S 2^{\underline{o}}$ Os conteúdos referentes à história e cultura afro-brasileira e dos povos indígenas brasileiros serão ministrados no âmbito de todo o currículo escolar, em especial nas áreas de educação artística e de literatura e história brasileiras. (Redação dada pela Lei n ${ }^{\circ} 11.645$, de 2008).

O Parecer CNE/CP 003/2004 visou atender os propósitos expressos na Indicação CNE/CP 6/2002 e também regulamentar o artigo 26-A da LDB. Sua expressa consonância com os princípios da educação étnico-racial garante os patamares gerais a serem seguidos pelos profissionais da educação. Sabendo que apenas a sanção da Lei 10.639/03 não garante o cumprimento de seus pressupostos, torna-se necessário solucionar o seguinte problema:

- Identificar a abordagem da questão racial e da cultura afro-brasileira nos livros didáticos aprovados pelo MEC e utilizados nas escolas públicas de ensino fundamental do $\operatorname{DF}\left(5^{\circ}\right.$ ao $9^{\circ}$ ano de ensino).

Para isso parte-se da seguinte pergunta:

- Como a questão racial é tratada nos livros didáticos após a sanção da lei $10.639 / 2003$ ?

\section{Hipótese}

Tornou-se usual que a preparação de professores recém-formados e a formação continuada daqueles que exercem a profissão há mais tempo sejam debates recorrentes na elaboração de projetos e programas da política educacional brasileira.

Estes eixos de análise partem do pressuposto da existência de múltiplas variáveis entre o momento de emissão da mensagem feita pelo profissional de educação até a apropriação do conhecimento pelos estudantes que perpassam decisões, críticas e debates sobre os papéis a serem exercidos pelos sujeitos sociais envolvidos no processo de ensino-aprendizagem no cotidiano escolar.

Acredita-se que a forma como a diversidade é discutida ainda é mascarada pela suposta hierarquia de brancos sobre negros desde primórdios da escravidão africana, não colaborando para o processo pedagógico dos estudantes. Sendo assim, a hipótese é a seguinte: 
- "Os livros didáticos ainda não colaboram de forma efetiva para a desconstrução da discriminação racial dentro do espaço escolar, mesmo após a sanção da lei 10.639 que dá a obrigatoriedade de ensino da história e cultura afro-brasileira nas escolas." 


\section{JUSTIFICATIVA}

O tema pesquisado é de grande importância por se tratar de uma realidade presente no país, onde a discriminação racial ainda se faz presente nos espaços públicos e privados da sociedade.

Na perspectiva de atuar na defesa desses segmentos, torna-se parte da preparação para a prática profissional de Serviço Social analisar as várias expressões da questão social, dentre elas a ineficácia da educação formal, a discriminação por raça/cor, a exclusão social, possibilitando desta forma a reflexão do diferencial na elaboração das políticas sociais que possam englobar todas essas questões e estreitar as diferenças sócio-econômicas existentes entre os grupos humanos, tais como negros e brancos.

Apesar do texto da Constituição Federal de 1988 contemplar explicitamente como fundamento da República Federativa do Brasil a dignidade da pessoa humana, é no Título II Dos Direitos e Garantias Fundamentais, mais precisamente no Capitulo II - Dos Direitos Sociais que a Lei Maior prevê garantias para o cumprimento deste fundamento. O artigo quinto desse Capítulo prevê:

XLI - a lei punirá qualquer discriminação atentatória dos direitos e liberdades fundamentais;

XLII - a prática do racismo constitui crime inafiançável e imprescritível, sujeito à pena de reclusão, nos termos da lei.

Fazendo a relação que estes artigos têm entre si, percebe-se a punição de qualquer discriminação prevista pela Constituição Federal, mas por outro lado restringe a possibilidade de sanções punitivas àqueles sujeitos que pratiquem o racismo nos espaços das relações sociais. Nesse sentido, as discussões dos mecanismos de valorização do negro e de suas tradições culturais na sociedade brasileira tornam-se imperativos para o processo de inclusão social, além de ser referencial para a prática profissional de Serviço Social.

Cabe ressaltar que no ano passado a Lei 10.639/03 foi ampliada em seus artigos pela inclusão da temática indígena em todo o currículo escolar, e em especial nas disciplinas de literatura, histórica e cultura africana. 
No que ocorre contemporaneamente, o debate sobre o racismo foi recentemente ampliado com a aprovação da Lei no 12.288 , de 20 de julho de 2010 - Estatuto da Igualdade Racial. Chama-se a atenção para seu $4^{\circ}$ artigo disposto no Título I das Disposições preliminares:

Art. 4ํㅜ A participação da população negra, em condição de igualdade de oportunidade, na vida econômica, social, política e cultural do País será promovida, prioritariamente, por meio de:

I - inclusão nas políticas públicas de desenvolvimento econômico e social;

II - adoção de medidas, programas e políticas de ação afirmativa;

III - modificação das estruturas institucionais do Estado para o adequado enfrentamento e a superação das desigualdades étnicas decorrentes do preconceito e da discriminação étnica;

IV - promoção de ajustes normativos para aperfeiçoar o combate à discriminação étnica e às desigualdades étnicas em todas as suas manifestações individuais, institucionais e estruturais;

V - eliminação dos obstáculos históricos, socioculturais e institucionais que impedem a representação da diversidade étnica nas esferas pública e privada;

O tema é também de grande importância porque chama a atenção para fatores determinantes no êxito da construção da vida educacional para o coletivo e permitir identificar formas que possam contribuir nessa trajetória e as que carecem de um olhar mais crítico por partes das políticas sociais de educação e raça. Na prática existem vários meios de alcance para a eliminação da desigualdade racial, como a criação da Secretaria de Políticas de Promoção da Igualdade Racial (SEPPIR), criada em 2003.

Esta Secretaria desde sua criação tem a pauta de acompanhar e coordenar políticas de diferentes ministérios e outros órgãos públicos para a promoção da igualdade racial, participando inclusive da sanção da Lei 10. 639/03 e também a recente aprovação do Estatuto de Igualdade Racial, que apesar de ter sofrido mudanças significativas em sua proposta originária simboliza uma grande conquista para o movimento negro existente no país. Portanto, este estudo pretende seguir os objetivos mesmos de resguardar direitos e garantias fundamentais direcionados à população negra, trazendo ainda em si as contribuições da universidade para encontrar barreiras primitivas que ainda permeiam o imaginário social e assim dificultam o processo político-pedagógico dos estudantes.

Uma das frentes de luta desta Secretaria em torno da obrigatoriedade do ensino de cultura e história africana nas escolas públicas se trata do papel da transversalidade deste conteúdo nas diversas disciplinas ministradas, partindo do pressuposto que não é colocando fórmulas de convívio social e ditando regras de conduta para os estudantes que se dará a 
garantia de um diferencial sócio-político na amplitude do currículo formal. Ou seja, mesmo que o conteúdo de história e cultura africana esteja mais explicitamente encontrado nas disciplinas de história, artes e literatura, não se pode perder de vista o diferencial em se discutir a origem sócio-histórica da nação brasileira em todos os espaços e cursos ministrados em sala de aula, até porque a realidade não é um processo mecânico e pontual, então em sala de aula não poderia ser diferente.

Direcionada à política educacional, a Secretaria de Educação Continuada, Alfabetização e Diversidade (SECAD), criada em julho de 2004, tem como objetivo contribuir para a redução das desigualdades educacionais por meio de políticas públicas que ampliem o acesso à educação continuada, promovendo orientação a projetos políticopedagógicos voltados para os segmentos da população vítima de discriminação e de violência, incluindo indígenas e quilombolas.

Sobre o avanço da discussão da questão racial no Brasil, o dispositivo legal 10.639/2003 prevê a obrigatoriedade do ensino de história afro-brasileira nas escolas, partindo de alguns pressupostos a serem resguardados nos livros didáticos que, pelo que parece, não estavam sendo reconhecidos até então.

Para além da Lei 10.639/03, o parecer CNE-CP 003/2004, elaborado pela Professora Petronilha Beatriz Gonçalves foi fundamental para a compreensão do conteúdo da lei, pois discorre sobre as Diretrizes para sua implementação. São abordados os conteúdos e a necessidade da ressignificação de termos como "escravos africanos" para "africanos escravizados". A partir desse parecer também que se torna possível discutir cursos de formação voltados para a educação das relações étnico-raciais.

A inserção do negro ${ }^{2}$ na formação do Brasil é vista ainda apenas da origem escravocrata, sem se ater às contribuições desta população para a cultura nacional, ou melhor, para a formação da identidade brasileira.

Não se pode negar que o Brasil evoluiu em matéria de defesa e reconhecimento da população negra, e no âmbito escolar a problemática do racismo passou a ter um maior espaço para a discussão, no sentido da defesa intransigente dos direitos humanos.

A Universidade de Brasília foi a primeira a adotar o sistema de cotas em seu sistema de avaliação e desde então, muitas outras universidades também aderiram à ação afirmativa. Em 2009 a SEPPIR assinou um contrato de cooperação com o Conselho Nacional de desenvolvimento Científico e Tecnológico (CNPq/ Ministério da Ciência e Tecnologia) para a 
oferta de bolsas de iniciação científicas aos cotistas de 47 instituições públicas de ensino no valor de R\$ 300 mensais por um ano. Além das já citadas legislações estaduais sobre a vedação de livros didáticos que incitem o racismo.

No entanto, é com a inserção da questão racial como elemento obrigatório da educação formal que passa a ser possível a desmistificação da formação histórica brasileira e a valorização positiva do povo negro.

O debate sobre a questão racial sempre me causou instigação. Ao mesmo tempo em que iniciei a graduação no segundo semestre de 2006 ocorria o efervescente debate sobre o sistema de cotas na universidade, e esta relação só aumentou o meu interesse pela temática racial, direcionando assim as atividades não-obrigatórias no sentido de aprofundar o conhecimento e reflexão na área. Para tal, no primeiro semestre de 2008 participei da disciplina Pensamento Negro Contemporâneo, com a professora Deborah Santos, ofertada pelo Decanato de Extensão. Também nesse semestre participei de algumas atividades de extensão da UnB tal como “África: o que a mídia não vê".

Na realização do trabalho final da disciplina Pensamento Negro Contemporâneo me detive ao assunto dos Quilombos no Brasil, com o intuito de retratar o diferencial cultural destes sujeitos para a formação cultural do país, e também sobre a importância do planejamento de políticas públicas para esse segmento, inclusive de acesso às terras remanescentes de quilombos, que por mais que se constituíam em direitos adquiridos, ainda recebem retaliações governamentais quanto à sua efetivação. A partir daí comecei a visualizar a necessidade de se analisar o contexto sócio-histórico da inserção dos negros na população brasileira na perspectiva da história afro-brasileira, não deixando somente para o período escravocrata do país toda a responsabilidade de conteúdo.

No segundo semestre de 2009 iniciei uma pesquisa de iniciação científica com a Professora Débora Diniz sobre o ensino religioso nas escolas públicas, a partir da análise documental de documentos oficiais e extra-oficiais sobre o assunto, incluindo artigos, teses, dissertações e sítios religiosos. Para tanto, foi necessário visualizar a inserção de cada religião e seita religiosa no conteúdo programático da disciplina de ensino religioso nas escolas e de que forma as diretrizes curriculares influenciavam na decisão de conteúdo. Como esperado, a religião católica detém privilégios de sua ideologia na assimilação de conteúdo, enquanto as religiões de matriz africana têm falta de visibilidade e ainda são subvalorizadas no grau de prioridades da disciplina. A experiência desta pesquisa me permitiu conhecer e desenvolver técnicas de pesquisa documental. 
Pesquisando Trabalhos de Conclusão de Curso (TCC) no Departamento de Serviço Social e outros departamentos da Universidade de Brasília pode-se perceber que faltam estudos sobre a questão racial nos livros didáticos. Existem sim estudos que retratam a manutenção dos estudantes cotistas na universidade, como o estudo "Educação, raça e desigualdade social - Uma análise das respostas institucionais da Universidade de Brasília aos estudantes cotistas", monografia de autoria de Juliana Soares Lima que foi orientada pelo professor aposentado Mário Ângelo Silva. Recente, este estudo foi aprovado no ano de 2007.

Já sobre a relação de assistência social e raça no Brasil há o estudo "A problemática racial na política de assistência social no Brasil: o desafio da especificidade negra", monografia de autoria de Ângelo Roger de França Costa que foi orientada pela professora Rosa Helena Stein e aprovada em julho de 2008. No entanto, carecem estudos que retratem a história afro-brasileira da perspectiva de garantia dos direitos sociais.

Com um novo olhar sobre a questão racial, tornou-se imperativo buscar a origem das apreciações escolares sobre o assunto, e não só sob a perspectiva de direitos humanos e cidadania, mas compreender o significado dos signos e símbolos utilizados no material escolar e de que forma estes sinais contribuem ou não para a redução da desigualdade racial existente no Brasil.

No primeiro semestre de 2010, mesmo período de composição desta pesquisa, participei da disciplina Política de Educação com a professora Silvia Cristina Yannoulas, a fim de garantir elementos para se pensar a questão racial dentro do contexto sócio-político da educação, pensada atualmente a partir do padrão neoliberal de financiamento das políticas públicas. Com isso, foi possível aproximar-se mais da temática racial, especialmente no que toca o espaço escolar como fonte de propagação e discussão da discriminação racial.

Participei de uma reunião do Grupo de pesquisa em Educação e Políticas Públicas: Gênero, raça/etnia e juventude (GERAJU), também no primeiro semestre de 2010. Com essa participação pretendia encontrar caminhos possíveis para o meu PTCC, visto que ainda era início de semestre e eu só havia em mente que queria pesquisar algo que relacionasse educação e raça. Não continuei indo às reuniões por falta de tempo, mas tive a oportunidade de conversar com a professora Denise Botelho da Faculdade de Educação da UnB para que me fornecesse alguns subsídios para a pesquisa documental dos livros didáticos. Esta professora me indicou Sônia Maria Soares dos Reis, que atua na Coordenação de Acervo Bibliográfico da Secretaria de Estado da Educação do Distrito Federal (SEE/DF). Sua opinião 
era que esse espaço poderia me possibilitar o acesso aos livros didáticos requisitados para esta pesquisa.

Consideramos a importância deste estudo também pela sua relação direta com a sociedade. O reconhecimento da sociedade aos órgãos públicos criados para promover políticas públicas está diretamente relacionado à promoção de pesquisas sobre sua área de atuação, sabendo a melhor forma de planejar e avaliar o processo de criação e manutenção destas políticas. No caso da política educacional, o diagnóstico da potencialidade do material escolar utilizado servirá para a melhoria dos recursos destinados para esse fim, utilizando com racionalidade os recursos advindos da contribuição da sociedade.

As indagações e reflexões desta pesquisa podem beneficiar também o conhecimento científico na medida em que esta pesquisa problematiza como os livros didáticos estão realizando a discussão do processo sócio-histórico da população negra na sociedade brasileira e mostrando aspectos positivos e negativos da implementação da lei 10.639/03. Esta pesquisa pode servir de experiência para o conhecimento humano sobre o preconceito racial, e fazer novas provocações sobre as causas da desigualdade entre os grupos humanos existentes nos diversos espaços da sociedade.

Também como uma futura assistente social, torna-se imperativo zelar pelo compromisso ético-político da profissão em que um dos princípios fundamentais se trata no empenho pela eliminação de todas as formas de preconceito, incentivando o respeito à diversidade, à participação dos grupos socialmente discriminados e à discussão das diferenças. Sendo assim, a discussão sobre o conteúdo referente à questão racial nas escolas é de extrema importância, principalmente em se tratando de sujeitos sociais que se constroem para o presente e para o futuro de suas relações sociais dentro e fora do âmbito escolar.

No entanto como em qualquer outra pesquisa foram encontradas limitações, qual seja de investigação do tema proposto. Não foi possível no contexto de um TCC uma aproximação com o público-alvo dos livros didáticos. Para isso seria fundamental o movimento de ir às escolas, dialogar com os estudantes e o corpo docente, atentando assim a uma análise do impacto do conteúdo em que é abordada a questão racial nos livros didáticos. Cada pesquisa não só pode como tem o papel de instigar outros estudos que abasteçam o campo de reflexões gerado por pesquisas anteriores sobre determinado tema.

Desde o início a proposta deste trabalho se tratou de analisar os livros didáticos por meio da pesquisa documental, utilizando outras metodologias de pesquisa somente como suporte. Portanto, mesmo que a escolha da transmissão da mensagem possa interferir em 
resultados inesperados, tem-se a ciência de que este estudo coloca-se como uma etapa inicial e primordial para reflexões posteriores.

O coletivo necessita de fundamentações sobre o assunto para poder dialogar a respeito de mitos $^{3}$ reproduzidos na sociedade, como diz o Centro Latino-Americano em Sexualidade e Direitos Humanos (CLAM):

No Brasil, a soma das visões eurocêntricas e racistas resultou no dilema de constituir uma nação por meio do projeto homogeneização, ao mesmo tempo, pela necessidade de reinterpretar positivamente a presença de outros "selvagens", tão numerosos e tão próximos: os grupos indígenas que os europeus encontraram no continente e os grupos africanos trazidos compulsoriamente para cá (CLAM, 2009, p. 200).

3 De acordo com do Centro Latino-Americano em Sexualidade e Direitos Humanos (CLAM/IMS/UERJ), de 2009, os mitos nacionais são eventos ideológicos de grande força simbólica, de grande penetração em todos os discursos que circulam por esta sociedade - tais como a história oficial, a literatura, a mídia e os livros didáticos - capazes de condensar em uma mesma imagem ou idéia muitos significados simultâneos. 


\section{Capítulo I. PROCEDIMENTOS METODOLÓGICOS}

O processo de pesquisa requer a definição dos critérios de metodologia. Para esta pesquisa os livros didáticos foram fonte principal para a análise de dados, tendo como base a Lei 10.639/03.

Diante da amplitude de arcabouço teórico das obras didáticas, os livros de história foram ideais para a coleta de dados, visto que o questionamento desta pesquisa está diretamente relacionado à análise histórica da inserção do povo africano à cultura afrobrasileira e como essa inserção influenciou a compreensão do racismo na formação da sociedade brasileira.

\section{A Pesquisa documental}

Esta pesquisa foi desenvolvida através da análise documental e teve por fundamento conhecer alguns dos mecanismos de implementação da lei 10.639/2003, dentre eles o livro didático.

Como a técnica de pesquisa escolhida para esta pesquisa, a pesquisa documental possibilita a organização e compreensão de toda e qualquer leitura textual, a partir da desconstrução de frases e palavras inseridas no documento em análise, isto é, a partir da criação de categorias- chaves, interpretando-os de acordo com os objetivos da investigação proposta.

\footnotetext{
Os pesquisadores sociais têm a tendência de subestimar materiais textuais como dados. Os métodos de pesquisa passam por ciclos de moda e de esquecimento, mas a World Wide Web $(W W W)$ e os arquivos on-line para jornais, programas de rádio e televisão, criaram uma grande oportunidade para os dados em forma de textos. À medida que o esforço de coletar informações está tendendo a zero, estamos assistindo a um renovado interesse na análise de conteúdo (AC) e em suas técnicas, em particular em técnicas com o auxílio do computador (BAUER \& GASKELL, 2008, p. 189).
}

O tema "O ensino de história afro-brasileira nas escolas públicas" exigiu um resgate analítico das possibilidades de atuação no âmbito escolar a partir das condições teóricometodológicas dadas. A metodologia utilizada nesta pesquisa foi norteada pelo método 
qualitativo e buscou identificar a contribuição do conteúdo de história e cultura africana contido nos livros didáticos para a propagação da diversidade humana no espaço escolar a partir da promulgação da Lei 10.639/03. Para fins desta pesquisa foram considerados os livros didáticos utilizados no ensino fundamental desde a sanção da lei até os dias atuais.

Foram consultadas também as referidas leis: Constituição da República Federativa do Brasil de 1988, a Lei $n^{\circ} 10.639 / 03$, o parecer $n^{\circ} 3$ e a resolução $n^{\circ} 1$ de 2004 do Conselho Nacional de Educação sobre a implementação da referida legislação.

Não se pode deixar de analisar ainda as Leis $\mathrm{n}^{\circ} 7.716 / 89$ e sua modificante Lei $\mathrm{n}^{\circ}$ 9.459/97 que tipificam o crime de racismo no país. Conhecida ainda como a única legislação em discussão sobre o assunto no mundo. Em igual, o Estatuto da Igualdade Racial (Lei ${ }^{\circ}$ 12.288/10), recém-aprovado no Congresso Nacional, foi determinante para o estudo.

O Fundo Nacional do Desenvolvimento da Educação (FNDE) executa três programas voltados ao livro didático: o Programa Nacional do Livro Didático (PNLD), o Programa Nacional do Livro Didático para o Ensino Médio (PNLEM) e o Programa Nacional do Livro Didático para a Alfabetização de Jovens e Adultos (PNLA). A partir do conjunto de obras didáticas aprovadas por estes programas, cabe às próprias escolas escolherem suas obras de interesse.

Os resultados do processo de escolha são publicados no Diário Oficial da União (DOU), para conhecimento dos estados e municípios. Em caso de desconformidade, os estados e municípios podem solicitar alterações, desde que devidamente comprovada ocorrência de erros. Para uma melhor compreensão, ao final desta pesquisa há um anexo sobre o Edital do PNLD 2013 (página 80), que contém os princípios gerais de escolha das obras e seus critérios de exclusão.

Diante do processo de escolha dos livros didáticos a serem analisados nesta pesquisa, apontou-se a dificuldade em desvendar uma forma de acessá-los gratuitamente, pois ainda não era de conhecimento da pesquisadora a forma de acesso aos livros didáticos por outras via que não fossem a das escolas, que têm a garantia de distribuição da obras pelo MEC. A partir de pesquisas no sítio do FNDE foi localizado o Guia de Livros Didáticos do ano de 2011 para a disciplina de história no âmbito escolar. Nesse documento consta um processo avaliativo de desempenho do Ministério da Educação sobre o conjunto de obras didáticas aprovadas, a partir de princípios pré-estabelecidos considerados fundamentais para tal aprovação.

A escolha das obras didáticas seria feita através deste guia caso não fossem encontrados outros meios mais próximos, como através de um acervo bibliográfico próprio do 
DF. Oportunamente, a indicação da professora Denise Botelho me trouxe a possibilidade de tratar diretamente com uma pessoa que trabalha na Gerência de Tecnologias e Coordenação de Acervo Bibliográfico e livros didáticos da Secretaria de Estado de Educação do Distrito Federal, Sônia Maria Soares dos Reis. Por telefone marcamos uma visita a este espaço institucional visando uma aproximação das intenções e objetivos de minha pesquisa e o suporte que a instituição poderia me fornecer para a coleta das obras didáticas.

No dia 11 de junho de 2010 foi realizada visita ao Acervo Bibliográfico localizado no Setor de Indústria e Abastecimento (SIA), lote E, Unidade III, onde trabalha a Equipe do Livro Didático. Sônia Maria Soares dos Reis não se encontrava presente, quem me recebeu foi Francis Luli, professora de atividades de $1^{\mathrm{a}}$ a $4^{\mathrm{a}}$ série do ensino fundamental da Secretaria de Estado da Educação. Como ela se encontrava sozinha em seu setor no momento de minha visita, pediu para que outra pessoa me levasse aos depósitos onde são guardados os livros didáticos (referentes ao que se chama "reserva técnica"), ou seja, são reservas de livros que estão à disposição das escolas públicas quando for feito o pedido, podendo ser estes de nível fundamental e/ou médio.

Quem me acompanhou aos depósitos de livros foi Aldemir Ferreira de Brito, pessoa integrante do Grupo de Apoio da instituição. Este trabalhador me encaminhou a dois depósitos de livros em que pude ter acesso a diversas obras de todos os anos escolares e de todas as disciplinas ministradas nas escolas, inclusive história que é a disciplina estudada de principal interesse para esta pesquisa.

Percebeu-se que os referidos depósitos se encontram em condições precárias de higiene. As obras didáticas se encontram em amplos galpões, guardados no chão ou em cima de "papelões". Sendo assim, foi usual encontrar livros bastante empoeirados e amassados. Não há uma ordem de classificação, todos os livros são misturados nos diversos galpões, por isso que para realizar a coleta do material didático foi necessário visitar todos os locais de depósito.

Pode-se dizer, no entanto, que o principal objetivo da visita foi atendido: foram coletados livros didáticos de todos os anos escolares utilizados no ensino fundamental do DF, com exceção do $9^{\circ}$ (nono) ano, pois nenhuma obra foi localizada. Após o procedimento de recolher os livros didáticos, novamente fui ao encontro da professora Francis Lulis que me deu total consentimento para levá-los da instituição. Apenas foi pedido que eu assinasse um documento citando o número de livros que estava levando (no total foram 29 livros) e a área de interesse: história. 
Em diálogo com a professora Silvia Cristina Yannoulas, minha orientadora, foi pensada a possibilidade de inserir livros didáticos de geografia na análise de dados, como forma de subsidiar o estudo da questão racial e sua abordagem documental e visual. Assim, no dia 04 de outubro de 2010 compareci novamente ao Acervo Bibliográfico. A professora de atividades Roseni Luiza de Sousa me recebeu e disponibilizou livros didáticos de geografia encontrados nos depósitos do acervo.

Após a análise do material recolhido no acervo bibliográfico visitado foram escolhidos quatro livros de interesse, citados a seguir de acordo com o ano escolar referente a obras de $5^{\circ}$ ano e $6^{\mathrm{a}}$ a $8^{\mathrm{a}}$ série respectivamente: Projeto Pitanguá, de Maria Raquel Apolinário Melani da editora Moderna, ano de edição 2008; Descobrindo a história, de Sônia Mozer e Vera Telles, da editora Ática, edição de 2007; Saber e fazer história, de Gilberto Cotrim, editora Saraiva, edição de 2006 e por fim a obra Construindo consciências, de Leonel Itaussu de A. Mello e Luís César Amad Costa, editora Scipione, edição de 2008. Para uma melhor visualização do material didático coletado, se dispõe a seguir as listas de quadros dos livros de geografia e história coletados:

Quadro N. 1 LIVROS DIDÁTICOS - História

\begin{tabular}{|c|c|c|c|c|}
\hline $\begin{array}{c}\text { Ano de } \\
\text { ensino }\end{array}$ & Título & Coleção & $\begin{array}{c}\text { Editora/ano } \\
\text { de edição }\end{array}$ & Autores \\
\hline \multirow{2}{*}{$\mathbf{1}$ ano } & $\begin{array}{c}\text { De olho no futuro } \\
\text { PNLD 2007/2009 }\end{array}$ & $\begin{array}{c}\text { De olho no } \\
\text { futuro }\end{array}$ & $\begin{array}{c}\text { Quinteto } \\
\text { Editorial } \\
(2005)\end{array}$ & $\begin{array}{c}\text { Thatiane Pinela } \\
\text { Giaretta }\end{array}$ \\
\cline { 2 - 5 } & $\begin{array}{c}\text { Porta Aberta } \\
\text { História } \\
\text { PNLD 2007 }\end{array}$ & Porta Aberta & FTD (2005) & Mirna Lima \\
\hline
\end{tabular}




\begin{tabular}{|c|c|c|c|c|}
\hline \multirow[t]{4}{*}{$2^{\circ}$ ano } & $\begin{array}{c}\text { História } \\
\text { PNLD 2010/2012 }\end{array}$ & $\begin{array}{l}\text { Conhecer e } \\
\text { crescer }\end{array}$ & $\begin{array}{c}\text { Escala } \\
\text { educacional } \\
(2008)\end{array}$ & $\begin{array}{c}\text { AdrianaVenâncio } \\
\& \\
\text { Katsue Zenun } \\
\& \\
\text { Mônica } \\
\text { Markunas }\end{array}$ \\
\hline & $\begin{array}{l}\text { Projeto Pitanguá } \\
\text { PNLD 2010/2012 }\end{array}$ & & $\begin{array}{c}\text { Moderna } \\
\text { (2008) }\end{array}$ & $\begin{array}{c}\text { Maria Raquel } \\
\text { Apolinário } \\
\text { Melani }\end{array}$ \\
\hline & $\begin{array}{l}\text { A escola é nossa } \\
\text { PNLD 2010/2012 }\end{array}$ & $\begin{array}{c}\text { A escola é } \\
\text { nossa }\end{array}$ & $\begin{array}{c}\text { Scipione } \\
(2010)\end{array}$ & $\begin{array}{c}\text { Rosemeire Alves } \\
\qquad \& \\
\text { Maria Eugênia } \\
\text { Bellusci }\end{array}$ \\
\hline & $\begin{array}{c}\text { História } \\
\text { PNLD 2010/2012 }\end{array}$ & $\begin{array}{c}\text { Pelos } \\
\text { caminhos da } \\
\text { história }\end{array}$ & $\begin{array}{l}\text { Positivo } \\
(2008)\end{array}$ & $\begin{array}{c}\text { Flávio Berutti } \\
\qquad \& \\
\text { Adhemar } \\
\text { Marques }\end{array}$ \\
\hline
\end{tabular}




\begin{tabular}{|c|c|c|c|c|}
\hline $\begin{array}{l}\text { Ano de } \\
\text { ensino }\end{array}$ & Título & Coleção & $\begin{array}{c}\text { Editora/ano } \\
\text { de edição }\end{array}$ & Autores \\
\hline \multirow[t]{3}{*}{$3^{\circ}$ ano } & $\begin{array}{c}\text { Projeto Prosa } \\
\text { PNLD } \\
2010 / 2012\end{array}$ & & $\begin{array}{l}\text { Saraiva } \\
(2008)\end{array}$ & $\begin{array}{c}\text { Alexandre Alves } \\
\& \\
\text { Letícia } \\
\text { Fagundes de } \\
\text { Oliveira } \\
\& \\
\text { Regina } \\
\text { Nogueira } \\
\text { Borella }\end{array}$ \\
\hline & $\begin{array}{c}\text { Porta Aberta } \\
\text { PNLD } \\
\text { 2010/2012 }\end{array}$ & Porta Aberta & $\begin{array}{l}\text { FTD } \\
(2005)\end{array}$ & Mirna Lima \\
\hline & $\begin{array}{c}\text { Vivência e } \\
\text { construção - } \\
\text { História } \\
\text { PNLD } 2005\end{array}$ & & $\begin{array}{l}\text { Ática } \\
\text { (2005) }\end{array}$ & $\begin{array}{c}\text { J. William } \\
\text { Vesentini } \\
\& \\
\text { Dora Martins } \\
\& \\
\text { Marlene Pécora }\end{array}$ \\
\hline \multirow[t]{2}{*}{$4^{\circ}$ ano } & $\begin{array}{c}\text { A escola é nossa } \\
\text { PNLD } \\
2010 / 2012\end{array}$ & A escola é nossa & $\begin{array}{l}\text { Scipione } \\
\text { (2010) }\end{array}$ & $\begin{array}{c}\text { Rosemeire } \\
\text { Alves } \\
\& \\
\text { Maria Eugênia } \\
\text { Bellusci }\end{array}$ \\
\hline & $\begin{array}{c}\text { História } \\
\text { PNLD } 2007\end{array}$ & & $\begin{array}{l}\text { Ática } \\
\text { (2007) }\end{array}$ & $\begin{array}{c}\text { J. William } \\
\text { Vesentini } \\
\text { \&Dora Martins } \\
\text { \&Marlene } \\
\text { Pécora }\end{array}$ \\
\hline
\end{tabular}




\begin{tabular}{|c|c|c|c|c|}
\hline $\begin{array}{l}\text { Ano de } \\
\text { ensino }\end{array}$ & Título & Coleção & $\begin{array}{c}\text { Editora/ano } \\
\text { de edição }\end{array}$ & Autores \\
\hline \multirow[t]{3}{*}{$4^{\circ}$ ano } & $\begin{array}{c}\text { Vivência e } \\
\text { construção- } \\
\text { História } \\
\text { PNLD } 2005\end{array}$ & & $\begin{array}{l}\text { Ática } \\
\text { (2005) }\end{array}$ & $\begin{array}{c}\text { J. William } \\
\text { Vesentini } \\
\& \\
\text { Dora Martins } \\
\& \\
\text { Marlene Pécora }\end{array}$ \\
\hline & $\begin{array}{c}\text { História } \\
\text { PNLD } 2004 \\
\text { *Aprovado pelo } \\
\text { MEC com } \\
\text { recomendação }\end{array}$ & Pensar e viver & $\begin{array}{l}\text { Ática } \\
\text { (2003) }\end{array}$ & $\begin{array}{c}\text { Rosaly Braga } \\
\text { Chianca } \\
\& \\
\text { Francisco M. P. } \\
\text { Teixeira }\end{array}$ \\
\hline & $\begin{array}{l}\text { De olho no } \\
\quad \text { futuro } \\
\text { PNLD } \\
2007 / 2009\end{array}$ & $\begin{array}{l}\text { De olho no } \\
\text { futuro }\end{array}$ & $\begin{array}{c}\text { Quinteto } \\
\text { Editorial } \\
\text { (2005) }\end{array}$ & $\begin{array}{c}\text { Thatiane Pinela } \\
\& \\
\text { Liz Andréia } \\
\text { Giaretta }\end{array}$ \\
\hline \multirow[t]{2}{*}{$5^{\circ}$ ano } & $\begin{array}{c}\text { Projeto } \\
\text { Pitanguá } \\
\text { PNLD } \\
2010 / 2012\end{array}$ & & $\begin{array}{l}\text { Moderna } \\
\text { (2008) }\end{array}$ & $\begin{array}{c}\text { Maria Raquel } \\
\text { Apolinário } \\
\text { Melani }\end{array}$ \\
\hline & $\begin{array}{c}\text { Descobrindo a } \\
\text { história } \\
\text { * PNLD não } \\
\text { identificada }\end{array}$ & & $\begin{array}{l}\text { Ática } \\
\text { (2002) }\end{array}$ & $\begin{array}{c}\text { Sônia Mozer } \\
\qquad \\
\text { Vera Telles }\end{array}$ \\
\hline
\end{tabular}




\begin{tabular}{|c|c|c|c|c|}
\hline $\begin{array}{l}\text { Ano de } \\
\text { ensino }\end{array}$ & Título & Coleção & $\begin{array}{c}\text { Editora/ano } \\
\text { de edição }\end{array}$ & Autores \\
\hline \multirow{4}{*}{$6^{\circ}$ ano } & $\begin{array}{c}\text { Projeto Araribá } \\
\text { PNLD } \\
2008 / 2010\end{array}$ & & $\begin{array}{l}\text { Moderna } \\
\text { (2006) }\end{array}$ & $\begin{array}{c}\text { Maria Raquel } \\
\text { Apolinário } \\
\text { Melani }\end{array}$ \\
\hline & $\begin{array}{l}\text { Saber e fazer } \\
\text { história } \\
\text { PNLD } 2006\end{array}$ & & $\begin{array}{l}\text { Saraiva } \\
(2005)\end{array}$ & Gilberto Cotrim \\
\hline & $\begin{array}{c}\text { Descobrindo a } \\
\text { história } \\
\text { PNLD } 2007\end{array}$ & & $\begin{array}{l}\text { Ática } \\
\text { (2007) }\end{array}$ & 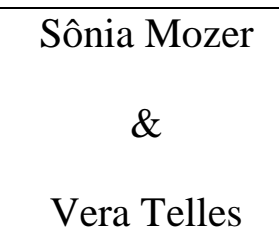 \\
\hline & $\begin{array}{c}\text { História - Das } \\
\text { cavernas ao } \\
\text { terceiro milênio } \\
\text { PNLD } \\
2008 / 2010\end{array}$ & & $\begin{array}{c}\text { Moderna } \\
\text { (2006) }\end{array}$ & $\begin{array}{c}\text { Patrícia Ramos } \\
\text { Braick } \\
\& \\
\text { Myriam Becho } \\
\text { Mota }\end{array}$ \\
\hline \multirow{2}{*}{$7^{\circ}$ ano } & $\begin{array}{l}\text { Saber e fazer } \\
\text { história } \\
\text { PNLD } 2007\end{array}$ & & $\begin{array}{l}\text { Saraiva } \\
\text { (2006) }\end{array}$ & Gilberto Cotrim \\
\hline & $\begin{array}{c}\text { Projeto Araribá } \\
\text { PNLD } \\
2008 / 2010\end{array}$ & & $\begin{array}{c}\text { Moderna } \\
\text { (2006) }\end{array}$ & $\begin{array}{c}\text { Maria Raquel } \\
\text { Apolinário } \\
\text { Melani }\end{array}$ \\
\hline $8^{\circ}$ ano & $\begin{array}{c}\text { Construindo } \\
\text { consciências } \\
\text { PNLD } \\
2008 / 2010\end{array}$ & & $\begin{array}{l}\text { Scipione } \\
\text { (2008) }\end{array}$ & $\begin{array}{c}\text { Leonel Itaussu } \\
\text { de A. Mello } \\
\& \\
\text { Luís César } \\
\text { Amad Costa }\end{array}$ \\
\hline
\end{tabular}




\begin{tabular}{|c|c|c|c|c|}
\hline & $\begin{array}{c}\text { Descobrindo a } \\
\text { história } \\
\text { * PNLD não } \\
\text { identificada }\end{array}$ & Ática & Elio Bonifazi \\
& & $(2003)$ & $\begin{array}{c}\text { Umberto } \\
\text { Dellamonica }\end{array}$ \\
\hline
\end{tabular}

Fonte: Gerência de Tecnologias - Coordenação de Acervo Bibliográfico e livros didáticos (GTEC/CBL) - Secretaria de Estado de Educação do Distrito Federal 
Quadro N. 2 - LIVROS DIDÁTICOS - Geografia

\begin{tabular}{|c|c|c|c|c|}
\hline $\begin{array}{c}\text { Ano de } \\
\text { ensino }\end{array}$ & Título & Coleção & $\begin{array}{c}\text { Editora/Ano } \\
\text { de Edição }\end{array}$ & Autores \\
\hline $6^{\circ}$ ano & $\begin{array}{c}\text { O espaço } \\
\text { natural e a ação } \\
\text { humana } \\
\text { PNLD } \\
\text { 2008/2010 }\end{array}$ & $\begin{array}{c}\text { Geografia } \\
\text { Crítica }\end{array}$ & $\begin{array}{l}\text { Ática } \\
\text { (2008) }\end{array}$ & $\begin{array}{c}\text { J. William } \\
\text { Vesentini \& } \\
\text { Vânia Vlach }\end{array}$ \\
\hline \multirow[t]{2}{*}{$7^{\circ}$ ano } & $\begin{array}{c}\text { O espaço social } \\
\text { e o espaço } \\
\text { brasileiro } \\
\text { PNLD } \\
2008 / 2010\end{array}$ & $\begin{array}{c}\text { Geografia } \\
\text { Crítica }\end{array}$ & $\begin{array}{l}\text { Ática } \\
\text { (2008) }\end{array}$ & $\begin{array}{c}\text { J. William } \\
\text { Vesentini } \\
\qquad \& \\
\text { Vânia Blach }\end{array}$ \\
\hline & $\begin{array}{c}\text { Projeto Araribá } \\
\text { PNLD } \\
2008 / 2010\end{array}$ & & $\begin{array}{l}\text { Moderna } \\
\text { (2006) }\end{array}$ & Virginia Aoki \\
\hline $8^{\circ}$ ano & $\begin{array}{c}\text { Geografia - } O \\
\text { mundo } \\
\text { subdesenvolvido } \\
\text { PNLD } \\
2008 / 2010\end{array}$ & & $\begin{array}{c}\text { Moderna } \\
\text { (2006) }\end{array}$ & Melhem Adas \\
\hline
\end{tabular}




\begin{tabular}{|c|c|c|c|c|}
\hline $\begin{array}{l}\text { Ano de } \\
\text { ensino }\end{array}$ & Título & Coleção & $\begin{array}{c}\text { Editora/Ano } \\
\text { de Edição }\end{array}$ & Autores \\
\hline \multirow[t]{2}{*}{$8^{\circ}$ ano } & $\begin{array}{c}\text { Geografia do } \\
\text { mundo } \\
\text { subdesenvolvido } \\
\text { PNLD } \\
\text { 2008/2010 }\end{array}$ & & $\begin{array}{l}\text { Ática } \\
\text { (2008) }\end{array}$ & $\begin{array}{l}\text { J. William } \\
\text { Vesentini } \\
\qquad \& \\
\text { Vânia Vlach }\end{array}$ \\
\hline & $\begin{array}{c}\text { Construindo a } \\
\text { Geografia - A } \\
\text { América e o } \\
\text { Mundo } \\
\text { PNLD } \\
\text { 2008/2010 }\end{array}$ & & $\begin{array}{c}\text { Moderna } \\
\text { (2005) }\end{array}$ & $\begin{array}{c}\text { Regina Araújo } \\
\& \\
\text { Raul Borges } \\
\text { Guimarães } \\
\& \\
\text { Wagner Ribeiro }\end{array}$ \\
\hline
\end{tabular}

Fonte: Gerência de Tecnologias - Coordenação de Acervo Bibliográfico e livros didáticos (GTEC/CBL) - Secretaria de Estado de Educação do Distrito Federal

Cabe ressaltar que a análise de dados limitou-se ao campo teórico da disciplina de história, visto que a análise realizada tomou boa parte da composição da monografia, além disso, também foi vista como suficiente para o pressuposto de pesquisa tal qual era a abordagem racial percebida nos livros didáticos.

Para a escolha das obras supracitadas tomou-se como critério principal ser de editoras diferentes. No entanto, o critério de obras mais recentes não pôde ser totalmente preservado já que 14 das 25 obras de história relacionadas são de Programas Nacionais do Livro Didático Ensino Fundamental (PNLD) passados. 
É importante assinalar que algumas das edições das obras acima citadas e escolhidas para a pesquisa documental ainda se referem às antigas "séries escolares", devido à mudança na legislação ${ }^{4}$ que aumentou de oito para nove anos o ensino fundamental.

Para efeitos desta pesquisa tomou-se o cuidado de diferenciar as obras antigas das novas no momento de análise dos dados, no entanto, para facilitar a visualização dos livros didáticos nos quadros explicativos, colocou-se apenas a categoria "ano de ensino", tendo por base a nova legislação em vigor.

Antes de selecionar quais seriam os livros didáticos analisados, foi estabelecido que não mais de cinco obras seriam analisadas, porque não haveria tempo suficiente e foi aceitável para a intenção principal de provocar um assunto ainda pouco explorado em trabalhos científicos da universidade. Dentre as 25 obras, selecionaram-se então obras do segundo ciclo do ensino fundamental ( $6^{\circ}$ ao $9^{\circ}$ ano e de $5^{\text {a }}$ a $8^{\mathrm{a}}$ série $)$.

Após esta seleção então se tomou novamente o critério de editoras diferentes, para que a análise não ficasse comprometida com a singularidade de conteúdos abordados de certa editora, podendo assim compreender condições de abordagem teórica e suas nuances diferenciadas de editora para editora. Após o fim da análise, apenas um livro escolhido era da nova PNLD (Projeto Pitanguá - $5^{\circ}$ ano), sendo os outros ainda da nomenclatura antiga: Descobrindo a história $-6^{\mathrm{a}}$ série, Saber e fazer história $-7^{\mathrm{a}}$ série e Construindo consciências $8^{\mathrm{a}}$ série.

Como o objetivo desta pesquisa foi visualizar a história afro-brasileira nos livros didáticos aprovados pelo MEC e utilizados nas escolas públicas do DF, a análise se focou nos capítulos relacionados à História Brasileira bem como as relações apresentadas com o continente africano, no que diz respeito da origem dos africanos escravizados. Durante a fase de análise de dados foi fundamental considerar todo e qualquer conteúdo relacionado à história afro-brasileira, desde tradições religiosas africanas até a resistência negra nos tempos de colonização. Com o intuito de realizar a correlação de potencialidades presentes em cada obra, deu-se preferência pela maior variedade de editoras possível.

Também para fins desta análise foram contabilizados o número de páginas disponíveis para o tratamento da questão racial e história afro-brasileira, feita de maneira comparativa com todos os livros didáticos analisados.

\footnotetext{
A aprovação da Lei $\mathrm{n}^{\circ}$. 11.274, em fevereiro de 2006, transforma o último ano da educação infantil no primeiro ano do ensino fundamental. A Classe de Alfabetização (fase anterior à $1^{\mathrm{a}}$ série, com matrícula obrigatória aos seis anos) que, até então, não fazia parte do ciclo obrigatório (a alfabetização na rede pública e em parte da rede particular era realizada normalmente na $1^{\mathrm{a}}$ série.
} 
Sabendo dos princípios do Ministério da Educação para a aprovação dos livros didáticos aferidos em sala de aula, esta pesquisa avaliou de modo subjetivo a efetividade do conteúdo em cada obra e os resultados esperados com a aplicação destes princípios.

Não foram necessários instrumentos de coleta visto que se abordou a pesquisa documental, no entanto, na fase de análise de dados foram feitos quadros explicativos com as principais categorias de análise encontradas nos livros didáticos, a fim de estabelecer padrões considerados fundamentais para ser ensinado em salas de aula e que norteiam a metodologia de ensino de história e cultura africana.

A pesquisa de campo

Em vista de subsidiar os dados obtidos, a pesquisa de campo foi realizada com pessoas que têm experiência com as relações raciais inseridas no âmbito educacional. Como fundamento tem-se a implementação da legislação em questão e o envolvimento direto do movimento negro para seu acontecimento.

A primeira entrevista ocorreu com a pedagoga e historiadora Maria Auxiliadora Lopes, que trabalha na SECAD, por essa Secretaria ser um instrumento governamental e político essencial para a proteção e garantia da política educacional. Durante a entrevista declarou não ter propriedade de conhecimento sobre os livros didáticos de história e geografia, apesar de ter fornecido subsídios a respeito da legislação sobre o assunto.

A segunda entrevista ocorreu com Ana José Marques, professora da Escola de Aperfeiçoamento para Professores (EAPE). Também declarou não ter experiência direta com os livros didáticos aplicados nas escolas.

Todas as entrevistas foram realizadas pessoalmente, sendo que o contato de Ana José Marques foi indicado por Maria Auxiliadora.

Os cuidados éticos foram tomados, sabendo que a pesquisa com seres humanos prevêem a proteção do entrevistado, sua autonomia em aceitar ou não participar da pesquisa, preservação de sua intimidade e vida pessoal, a asseguração da estima da pesquisa para a construção do conhecimento humano na prática da realidade (VIEIRA, 2008). A aplicação destas entrevistas foi acompanhada do Termo de Consentimento Livre e Esclarecido (TCLE), 
o qual expôs os argumentos e técnicas de pesquisa, assim como promoveu o fim das informações cedidas em entrevista. 


\title{
Capítulo II. A África na educação brasileira
}

\author{
A identidade étnica brasileira
}

A inclusão do ensino da história afro-brasileira no ensino brasileiro desfaz alguns estigmas, mas não suprime o fato dos africanos terem vindo como trabalhadores sem direito algum, vítimas de todo o tipo de violência que perdura até os dias de hoje, onde os mesmos são taxados como de capacidade intelectual inferior, preguiçosos e indolentes. A grande diferença é que hoje algumas lendas inventadas pelos opressores se desfazem. A resistência negra existiu sim. A capacidade de organização social dos africanos, mesmo com a mistura de pessoas vindas de diferentes países da África, com costumes, tradições e línguas diferentes não impediu sua organização social que foi muito bem demonstrada na formação dos quilombos, fazendo com que hoje tenhamos no Brasil uma cultura diferente de qualquer outra que exista na África.

A história da África e da cultura africana ainda é vista como desnecessária por parte da população brasileira que acha que no continente só tem selva, animais ferozes, a disseminação da AIDS e pobreza. A realidade do continente africano tem pontos em comum com a nossa. Os governos locais são manipulados pela corrupção dos representantes, o desvio de dinheiro público é uma prática reiterada em vários países. No entanto, essa realidade também é complexa, e certamente não é só isso que o continente tem para mostrar para o mundo.

É também necessário que os estudantes enxerguem além do senso comum, através dos livros didáticos que mostrem o lado histórico e cultural deste continente, nas especificidades de cada país, o processo de luta dos negros durante a escravidão e as contribuições para que o Brasil seja como ele é hoje: um país preenchido por diversas culturas e tradições desvalorizadas e esquecidas pelo imaginário social.

Estas compreensões no interior do âmbito escolar sofrem principalmente influência exterior, a influência dos valores e códigos morais da sociedade. Traduzindo um pouco melhor pode-se pensar a falta de sensibilidade ainda presente para as memórias históricas dos negros aqui advindos no período escravocrata (desde o período colonial até o Império), mas não só para este olhar eurocêntrico de colonização, como também o olhar de reafirmação de identidade étnica brasileira a partir da valorização cultural africana presente no país. 
Um ensino particularizado e mecânico podem causar saberes separados, com a função apenas dos estudantes não repetirem o ano e fixarem o conteúdo para as provas. Não é de hoje que a realidade da educação brasileira ocorre assim, e por isso ser considerada fundamental a análise dos fatores de mecanização do ensino.

Para entender o progresso da educação nas escolas é essencial que se tenha em mente como se deu a origem dos processos educativos na sociedade moderna. Um dos principais críticos teóricos da educação é Michael W. Apple, um especialista sobre o tema do Currículo nas escolas, inserido no contexto dos avanços do projeto neoliberal nos Estados Unidos da América.

De acordo com a leitura de Michael W. Apple (2005), os estudos do currículo começaram a aparecer naquele país na passagem do século XIX para o século XX, em que a principal preocupação era encontrar as melhores formas de preparar as "futuras" gerações da sociedade. A partir daí dá-se ênfase às disciplinas consideradas importantes, enquanto outras são deixadas de lado por não se encontrarem na definição de fundamental para o currículo oficial de ensino. A questão a ser definida é do alcance curricular acerca dos objetivos propostos sabendo que qualquer que seja a proposta de ensino é dentro de um processo de mercantilização da educação em que os avanços e retrocessos desta política se encontram atualmente.

Segundo Robert. W. Connell (2002) o currículo oficial é peça-chave para a compreensão da segregação dentro do espaço escolar, pois não colabora para a prática pedagógica da maioria e não acende métodos mais ativos de ensino. Em seu texto é dito:

\footnotetext{
Quando o progresso no currículo oficial é tomado como objetivo da intervenção, esse currículo deixa de ser criticado. Mas a experiência dos professores/as em escolas em desvantagem os/as tem levado, persistentemente a questioná-lo. Tópicos e textos convencionais, métodos de ensino e avaliação tradicionais tornam-se fontes de dificuldades sistemáticas. Eles produzem um tédio constante. Impô-los faz aumentar o problema da disciplina e, a partir do momento em que eles efetivamente se fazem cumprir, dividem os alunos entre uma minoria academicamente bem sucedida e uma maioria academicamente desacreditada (Connell, 2002, p.27).
}

Tendo em vista as medidas neoliberais às quais a educação brasileira está submetida, sente-se a necessidade de reformulação do sistema por inteiro e também maior preocupação 
do Estado na busca de uma gestão democrática, onde todos tenham direito a uma educação de qualidade e não apenas de quantidade, o que não ocorre quando se aumenta o acesso à educação formal sem o devido acompanhamento da qualidade do processo ensinoaprendizagem. Nesse sentido, os livros didáticos refletem o que se espera que seja ensinado e que é incorporado pelo currículo oficial de ensino.

Ultrapassar as técnicas e metodologias de ensino tradicionais requer uma participação mais coletiva e democrática dos objetivos e práticas de ensino, ou seja, compreender as particularidades de vivências sociais que englobam os sujeitos nelas envolvidos. Infelizmente não se limitam os obstáculos encontrados para o desenvolvimento de uma prática mais coparticipativa, portanto há de se considerar mais horizontes, sendo o conteúdo dos livros didáticos de fundamental importância. 


\title{
Capítulo III. Lei 11.639/03
}

\author{
Movimento Negro e Educação
}

Segundo Florestan Fernandes, o movimento negro, em particular a Frente Negra Brasileira (FNB), foi o primeiro movimento de massa no período pós-abolicionista que teve o objetivo de inserir o negro na política (FERNANDES, 1978).

Atualmente o Movimento Negro é considerado como a peça fundamental para o embate político em prol da população negra neste país. Para a compreensão dos particularismos envolvidos no pertencimento racial, esta pesquisa partiu da metodologia de estudo do autor supracitado em seu ensaio "A integração do Negro na Sociedade de Classes".

Para além da transformação de "ser escravocrata" para "ser livre", é a partir da compreensão do marco histórico deixado pela sociedade escravocrata que os contornos temporais não se colocam mais suficientes para explicar a exclusão social da qual o negro foi penalizado com a abolição da escravidão e expansão da lavoura cafeeira nos fins do século XX. Florestan Fernandes explica esta questão dizendo que:

O que quer dizer que a desorganização da vida do negro prende-se, diretamente, à dupla impossibilidade - de abandonar, subitamente, os traços culturais herdados da escravidão; e de contrair, prontamente, os padrões de comportamento valorizado.

Ao longo do século XX, frentes de luta como a Frente Negra Brasileira (FNB) e o Movimento Negro Unificado (MNU) conquistaram espaço na mídia social para divulgação de suas demandas, dentre elas a educação formal. A educação formal sempre se constituiu um marco no panorama das reivindicações do Movimento Negro na luta por uma sociedade mais justa e igualitária (SECAD, 2010).

As opiniões dos entrevistados sobre o Movimento Negro na Educação

De acordo com o relato cedido sobre a atuação do Movimento Negro na educação, a desmistificação da democracia racial ao longo do século XX se deve principalmente a este 
movimento social. Das reivindicações do Movimento Negro uma delas foi uma leitura crítica dos estudantes sobre a história da cultura afro-brasileira. Mesmo que o livro didático não seja material suficiente para o debate da educação das relações raciais no ambiente escolar, o processo de reivindicação de vontade política voltada para o movimento negro não foi de tal forma simplificada.

Segundo as entrevistadas, as legislações 10.639/03, Parecer CNE/CP 003/2004 e Resolução CNE/CP No 001/2004 são fruto da luta do movimento negro no Brasil. Cabe ressaltar que as entrevistas compreendem esta luta não só no espaço de tempo de sanção e implementação da Lei 10.639/03 até os dias atuais, como também o período da década de 1960 e 1970, em que movimentos como FNB e MNU fizeram parte.

Mesmo que em linhas gerais a luta em prol da inserção do negro no livro didático tenha adquirido destaque na mídia apenas na década passada, para o movimento negro e para suas reivindicações sócio-políticas em períodos passados, esse pleito foi sempre presente.

Concorrentes com a ascensão dos movimentos sociais no Brasil, na década de 1970, era de se esperar que o principal questionamento da comunidade negra do país fosse a falta de integração nos âmbitos social, político e econômico que formavam os espaços públicos presentes. Embasado o processo educacional como meio de libertação dos sujeitos e de obtenção de julgamento crítico sobre os valores e normas perpetuados nesses mesmos espaços, o negro tomou para si o poder de reivindicação política que não tinha acesso até então.

\section{Desafios e limites à prática educacional}

Apesar do marco legislativo da Lei 11.639/03 encontrar resistências na prática educacional para sua implementação, as mudanças nele propostas têm como objetivo criar novas mentalidades na população brasileira, de modo a incentivar a valorização das pessoas indígenas e negras, e das diversas tradições que fazem parte da nação brasileira (ABRAMOVAY, 2009, p. 205).

Desafios e limites à atuação de uma prática educacional voltada para a emancipação de valores libertadores e igualitários são sempre consideráveis, mas as possibilidades de ação estão postas até mesmo onde não se acredita estar, ou pelo menos, não se acreditava. Diante da complexidade da inclusão de conteúdo das disciplinas escolares, e do conteúdo de história 
e cultura afro-brasileira em particular, encontram-se formas de representações do negro na sociedade brasileira que além de reproduzir tradições e crenças culturais também permitem a desmistificação de símbolos pejorativos e diminutivos ainda recorrentes no imaginário social.

Pode-se comprovar a particularidade desta discussão na pesquisa realizada pelo organismo internacional de Rede de Informação Tecnológica Latino-Americana (RITLA), no ano de 2009, em escolas públicas do Distrito Federal sobre as mais diversas concepções de violências presentes nas escolas, dentre elas as formas de perpetração da discriminação racial. Durante a realização de questões abertas de questionário, entrevistas e grupos focais das pesquisas Revelando tramas, descobrindo segredos: violência e convivência nas escolas foram relatados apelidos usados em insultos contra pessoas negras que se multiplicam e diversificam ao longo do tempo.

No caso do uso de palavras pejorativas, torna-se explícito a falta de sensibilidade sobre a discussão do pertencimento racial brasileiro. Os livros didáticos podem e devem contribuir para a discussão e o debate constante em sala de aula, dar condições para a formação de cidadãos conscientes. Isto significa que os livros não podem conter textos e imagens que estimulem à incitação do preconceito e discriminação, como também não podem estimular a propagação de símbolos e identidades religiosas sabendo que o Estado brasileiro é laico por direito.

Sendo assim, o livro didático pode ser considerado uma representação do corpo político e educacional presente, e por via de conseqüência das relações contraditórias, permitindo identificar a importância desse instrumento de comunicação, integrante da “tradição escolar” há pelo menos dois séculos.

Não existem definições precisas sobre o significado do livro didático, apesar da certa familiaridade que percorre sua propagação no âmbito escolar. No entanto, articulam-se funções e objetivos que devem perpassar o conteúdo das obras, dependendo das condições, do lugar e do momento em que são produzidos e utilizados. No caso do Guia do Livro Didático de História que rege as diretrizes e normas para o ensino público, se destacam funções que preservam o caráter participativo e refletido de escolha do livro didático.

Os livros didáticos são livremente escolhidos pelas escolas participantes, por meio de seu corpo docente e dirigente e com base na análise das informações contidas no Guia de Livros Didáticos. O mundo como o conhecemos e o experimentamos, isto é, o mundo representado e não o mundo em si mesmo, é constituído através de processos de comunicação (Luckmann, 1995 apud Bauer \& Gaskell, 2008). 
Esses processos existem no âmbito escolar pelos textos, imagens e sons. A comunicação sonora é dada através de materiais didáticos e pela própria personificação dos profissionais em sala de aula. $\mathrm{O}$ arcabouço textual e imaginativo corresponde aos conteúdos das obras didáticas.

Entre as competências esperadas para o conteúdo de história encontrado nos livros didáticos se encontram o respeito à legislação educacional, e pode-se esperar então que a Lei 10.639/03 se faça cumprir no âmbito escolar, a presença de qualidade pedagógica e didática das coleções, ou seja, seu corpo deve ser claro e preciso, de acordo com o que orientou sua confecção e a aprovação pelo Ministério da Educação por tal material didático.

De acordo com o Guia de livros didáticos atual, este princípio de qualidade e didática do livro didático deve transparecer a pluralidade, por se acreditar que o professor e a escola devem ter a prerrogativa de escolha daquilo que for mais pertinente e adequado para o Projeto Pedagógico definido no coletivo de sua instituição.

No caso da História isso significa que há a possibilidade de se lidar tanto com coleções que valorizem a aquisição da informação sobre o que aconteceu no passado, considerando-se, nesse caso, a História como o estudo da evolução humana ao longo do tempo, quanto é possível se avançar em direção aos princípios mais contemporâneos envolvendo a produção do conhecimento no âmbito da ciência histórica. Nesse caso, o acúmulo de informações a respeito do que aconteceu no passado cede espaço a uma atitude formativa mais global e a função educativa da História passa a ser considerada em função de se compreender a natureza da História como forma particular de conhecimento, pautada pela provisoriedade das explicações, continuamente reescritas. (GUIA DE LIVROS DIDÁTICOS, 2010, p. 11)

Dentro da lógica mercadológica e capitalista que perpassa a sociedade como um todo nos dias atuais, o livro didático se tornou um produto cultural de conhecimento que fornece os alicerces para a veiculação de valores ideológicos e culturais que interessam para o poder hegemônico e dominante de um povo. Como diz Robert W. Connell (2002):

\footnotetext{
A aparentemente remota disciplina de história do currículo contribuiu de maneira decisiva para se repensar as questões de pobreza e educação. Ela desmistificou o currículo hegemônico, mostrando como ele constitui apenas um dentre vários modos pelos quais o conhecimento poderia ter sido organizado para transmissão nas escolas (Connell, 2002, p. 28).
}

Sob este aspecto do currículo Robert W. Connell colocou à discussão que estão abertas as possibilidades de propostas de currículos alternativos, não implicando em apenas uma 
mudança para conteúdos diferentes como também e principalmente uma organização diferente do campo do conhecimento como um todo.

Não é só na nação brasileira que se percebe a importância da discussão e o debate da discriminação racial a partir do comprometimento do conteúdo dos livros didáticos como subsídio para a emancipação de valores e crenças africanas na base cultural deste país. Gloria Ladson-Billings (2008) põe em pauta as dificuldades encontradas na prática educacional de escolas norte-americanas para a conquista de novos entrelaçamentos nas relações sociais, mais precisamente entre negros e brancos, quando diz:

A crença da maioria dos estudantes - de que a escravidão dos afro-americanos há mais de cem anos explica as disparidades de hoje - sugere que eles não conseguiam imaginar como as condições podiam ser diferentes. A escravidão de afro-americanos é parte da história. Conseqüentemente, de acordo com essa visão o passado, por si só, determina o futuro de um povo (Ladson-Billings, 2008, p. 51).

Colocando as provocações que esta pesquisa esperou originar, a implementação de livros didáticos de história com a inserção de história e cultura africana em seus tópicos de ensino representaram avanços na política educacional, contudo se vista pelo viés da obrigatoriedade, tem-se que a questão racial ainda não é compreendida e perpassada pela sociedade como um todo. Se assim o fosse não haveria a necessidade da sanção de uma lei que coloca a obrigatoriedade deste ensino e o controle do conteúdo de história encontrado nos livros didáticos. Como a própria autora diz:

O ensino culturalmente relevante usa a cultura do aluno para preservá-la e transcender os efeitos negativos da cultura dominante. Os efeitos negativos são causados, por exemplo, por não se perceber a história, cultura ou antecedentes descritos nos livros didáticos ou currículos, ou por se enxergar aquela história, cultura e antecedentes de maneira distorcida (Ladson-Billings, 2008, p. 35).

As opiniões das entrevistadas sobre o papel institucional para a propagação da questão racial nas escolas

Segundo Ana José Marques, desde 2008 a EAPE possui um espaço chamado "Espaço Afrobrasilidade" introduzido pela professora Carmem Batista. Este espaço permite a 
introdução da temática racial dentro da instituição, oferecendo cursos para os professores da rede pública. Em 2010 foi criada ainda a Coordenação de Diversidade na qual a própria Ana Marque trabalha. Há três grandes áreas instituídas: a diversidade das relações étnico-raciais, da sexualidade e de gênero.

Admitiu ainda que atualmente são realizados encontros com o corpo docente da rede pública com sistema de idéias para futuros cursos de formação. Segundo Ana Marques estas ações permitirão a discussão não somente pontual sobre a questão racial nas escolas. Além disso, comentou que está sendo feita a Revisão Curricular do Ensino Médio, em que a Coordenação de Diversidade atualmente investe o debate com os professores sobre a educação das relações étnico-raciais.

Pensando o currículo como um objeto vivo, segundo a entrevistada a EAPE se propõe a discutir progressivamente com as editoras e escolas a importância de visibilizar a história afro-brasileira nos livros didáticos, deixando claro o papel da instituição para a propagação da questão racial nas escolas.

As opiniões das entrevistadas sobre a legislação e o livro didático

Ana Marques argumentou que a Lei 10.639/03 sustenta apenas parcialmente a legislação, sendo o Parecer CNE/CP 003/2004 e a Resolução CNE/CP 001/2004 mais significativos para a prática educacional. A formação de professores, especialmente, deve ser tratada de acordo com o parecer técnico do MEC, pois explicam como a legislação deve ser implementada.

Essa entrevistada prefere contextualizar como artigo 26-A que alterou a LDB, pela compreensão do termo "Lei 10.639/03" inferiorizar o alcance da legislação. "Os brasileiros acreditam ainda que existam leis que pegam e outras que não pegam" (sic). A LDB permitiu a ampliação da garantia de direitos, e desta vez, voltada para o negro, e devido ao seu histórico de maior legislação educacional do país permitiria uma maior visibilidade da questão racial. A introdução da questão racial nos livros didáticos significa também a disputa de espaços de poderes na sociedade.

O Conselho Nacional de Educação (CNE), o qual é responsável pela educação brasileira no âmbito legislativo, instruiu por meio de suas duas Câmaras: Câmara Básica e Câmara do Ensino Superior o caminho a ser traçado pelas escolas brasileiras. Por meio do 
parecer e resolução implementados em 2004 se iniciaria a mudança da organização curricular dos livros didáticos.

Outro ponto frisado durante as entrevistas foi de que o conteúdo voltado para esta cultura nos livros de história é apenas uma das possibilidades para o currículo oficial, sendo essencial também que o debate ocorra de forma transversal na educação formal. Prioritariamente nos componentes curriculares de história e literatura infanto-juvenil, não significa introduzir mecanicamente o conteúdo, mas sim, introduzir no dia-a-dia dos estudantes a problemática da questão racial, até mesmo em atos racistas acontecidos em sala de aula que muitas vezes não são discutidos.

Também foi criticado o fato do conteúdo voltado para a temática racial ser geralmente deixado para o final do período letivo, dando sinais de que seria menos importante que outros conteúdos. Conteúdos da Europa e América do Norte, por exemplo, teriam preferência na ordem cronológica do ensino, deixando como "possibilidade de fim de ano" o conteúdo do continente africano.

Indo além, percebeu-se a preocupação em compreender que o conteúdo da legislação não pretende anular o foco da cultura brasileira que invariavelmente é voltado para o referencial epistemológico europeu, mas sim permitir a ampliação do foco de culturais consideradas minoritárias, entre elas a africana e asiática.

No entanto, é também de acordo com a visão dos participantes desta pesquisa que as expectativas sobre o livro didático e sua função como propagador da cultura negra se transformaram. Não somente se esperava a inserção visual e textual sobre o tema, como também se estipularam condutas legais a respeito do conteúdo a ser lecionado. As denominadas diretrizes curriculares do MEC foram responsáveis por instruir técnicas e métodos da organização curricular de ensino.

\section{Serviço Social e Questão Racial}

Aprofundar o debate sobre Serviço Social e questão social requer também a compreensão das relações raciais que perpassam a sociedade, em se tratando de sociedade brasileira especialmente. Observa-se um sistema desigual de oportunidades que os sujeitos compartilham e em que o capital humano e cultural se faz presente a todo instante. 
A cultura e negritude africana são representadas desde a formação do Brasil Colônia, e demonstram que a exclusão social se coloca em roupagens de cada tempo, de acordo com a necessidade do capital, sendo monopolista ou não.

A existência de mecanismos que provocam a exclusão social da população negra não escapa de nenhuma esfera da função social, sendo inclusive parte da política educacional brasileira. Seguindo esse raciocínio que a SEPPIR promove políticas sociais voltadas para os grupos sociais que envolvem o negro na educação brasileira, como exemplo o sistema de cotas.

Mesmo que o profissional de Serviço Social já tenha se apropriado do debate de promoção das políticas sociais no Brasil, não se percebe tamanho avanço em se tratando da questão racial. Sendo esta uma urgente categoria que acompanha os critérios para uma análise crítica da realidade para o caminho da justiça social, o/a assistente social deve perceber este debate relacionando-o às nuances e particularidades que cultivam o segmento negro da população e percebendo que suas especificidades podem contestar o modelo de universalismo das políticas públicas implantado atualmente.

Ou seja, não se trata apenas de coibir o tratamento desigual ao sujeito coletivo como também colocar em pauta a discussão do direito às diferenças sócio-culturais existentes na totalidade da vida social. Sendo assim, a obrigatoriedade dos livros didáticos perpetuarem a cultura africana em sua organização curricular significa apenas um dos princípios e não torna pleno o papel da escola em garantir a emancipação das diferenças.

O debate das relações raciais deve ser também incluído no currículo oficial dos cursos de ensino superior, principalmente nos currículos de licenciatura, quais sejam: história, matemática, biologia, geografia, física e pedagogia. A discussão entre os estudantes antecipa a problemática que já se encontra nas escolas: o racismo institucional. O Serviço Social, como categoria profissional de apoio a eliminação de qualquer forma de discriminação racial e com o papel de promover a igualdade racial, tem o dever de incluir transversalmente em suas disciplinas esta discussão.

Neste contexto, a inserção dos assistentes sociais nas escolas pode ser vista como fundamental, já que seu papel é a garantia da educação como política pública através de diretrizes constitucionais, não somente com a democratização do acesso do sujeito à educação, mas, sobretudo à qualidade do ensino, a fim de promover o crescimento cultural do indivíduo enquanto cidadão (VIEIRA et al, 2010). 
Apesar de ser ainda projeto de lei a presença de assistentes sociais nas escolas, a intervenção do Serviço Social no processo educacional tem levantado cada vez mais debates sobre a importância deste profissional no âmbito escolar. Em seus três artigos, o Projeto de Lei $n^{\circ}$ 60/2007 busca assegurar o atendimento psicológico e de assistência social aos estudantes das escolas públicas de educação básica. Ele resulta de substitutivo da Comissão de Educação e Cultura da Câmara dos Deputados a nove proposições que tratavam do assunto, encabeçadas pela mais antiga, o Projeto de Lei $n^{\circ} 3.688 / 2000$, que originalmente dispunha apenas sobre a presença de assistentes sociais nas escolas públicas (VIEIRA et al, 2010).

O trabalho do assistente social se torna importante, inclusive, no sentido de mobilizar e incentivar a participação da comunidade nos espaços da escola e no processo de construção do projeto político-pedagógico. O que implica em um conhecimento mais profundo das reais demandas da comunidade, possibilitando a criação de um projeto relevante para esta, visando mudanças positivas na educação pensada no sentido de educar cidadãos, e não um exército de trabalhadores (VIEIRA et al, 2010).

Em diálogo com Maria Auxiliadora sobre o papel do Serviço Social em relação à promoção da igualdade racial no país e em especial da Lei 10.639/03 e correlata, a declarante observou sua precisa conscientização com relação às políticas públicas voltadas para a população negra justificada pela anterior aproximação do/a assistente social com as comunidades menos favorecidas da sociedade.

Sobre o posterior diálogo com Ana Marques a mesma afirmou ser fundamental o papel do Serviço Social na propagação de qualquer política voltada para o negro na sociedade brasileira, visto que o profissional de Serviço Social possui referenciais teóricos e práticos amplos para a compreensão das especificidades do povo negro e suas necessidades básicas.

A opinião das entrevistadas sobre a visibilidade do negro na sociedade brasileira

Questionamentos sobre a visão do negro na sociedade brasileira foram feitos pelas duas entrevistadas. Ana Marques destacou a visão deturpada e amplamente reproduzida na sociedade de que o negro só se encontra no futebol, tocando samba e lutando capoeira. Mais do que estudar o período escravocrata, a entrevistada admite ser essencial analisar contribuições do negro como os estudos científicos. O viés da escravidão não seria mais 
suficiente para a ascensão de valores igualitários e equiparáveis aos danos sofridos pelo negro por mais de trezentos anos.

Para tanto, o primeiro passo seria o reconhecimento da discriminação racial no país. Os rumos das políticas públicas demonstram já este reconhecimento, como a ampliação da LDB, e reivindicações para formulação de políticas públicas voltadas para o povo negro. 


\section{Capítulo IV: A história da África nos livros didáticos: descrição e análise de dados}

O primeiro livro analisado, denominado Projeto Pitanguá, é de autoria de Maria Raquel Apolinário Melani, da editora Moderna, edição de 2008. A obra didática fora elaborada para o $5^{\circ}$ ano do ensino fundamental de ensino. É dividida em três blocos de leitura, organizados em ordem cronológica a partir da colonização portuguesa nas terras brasileiras. Cada bloco é subdividido em três unidades. Além disso, contém sugestões de leitura ao final do livro.

O primeiro bloco, "Quando Portugal dominava o Brasil", aborda a dominação portuguesa em três fases: a infiltração portuguesa em território, a mineração no Brasil colonial e a independência do Brasil. A primeira identificação do negro se trata da produção do açúcar nos engenhos. "Escravos africanos" é a expressão utilizada para identificá-los. A elaboração da matéria-prima pela transformação da cana de açúcar é destacada por figuras ilustrativas. Simultaneamente, o negro aparece como peça-chave para a cultura trabalhista da época, ou seja, o cultivo e produção de cana de açúcar. Outra imagem com enfoque semelhante retrata a mineração realizada pelos escravos.

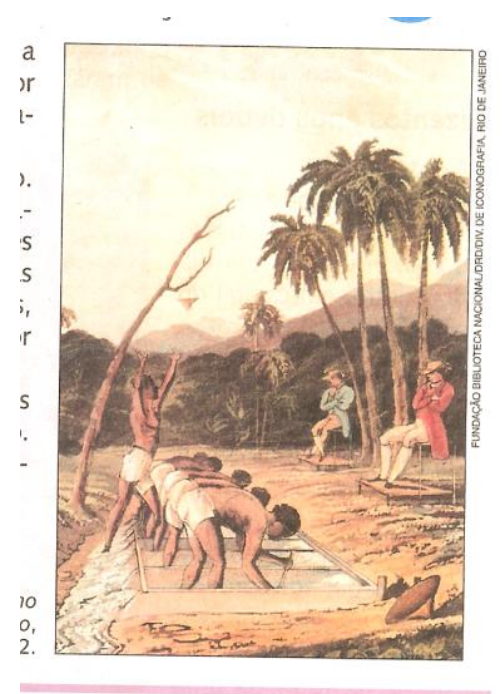

Também no caderno de atividades no final da segunda unidade consta um pequeno texto descrevendo a penosidade e insalubridade do trabalho nas minas, aos quais os negros estavam sujeitos à contaminação por gases e aos riscos de desabamento, entre outras doenças. No mesmo texto os quilombos são expressos como forma de revolta contra a escravidão. 
Outro ponto de servidão descrito no livro supracitado é sobre o sistema da coleta de esgoto que fora concebida pelos negros. Comparados a tigres pelas manchas que eram espalhadas enquanto faziam a limpeza das cidades.

Acerca da habitação depreende-se o inchaço de trabalhadores escravos nas senzalas, demonstrando seu grau de risco e precariedade. Com a informação de que até cem escravos conviviam no mesmo recinto e com uma imagem explícita do descaso, o desigual se torna o personagem branco que de trás da senzala apenas observa a pobreza e a miséria da habitação.

Na terceira e última unidade do primeiro bloco, cita-se a Conjuração Baiana como movimento de libertação daquela capitania hereditária, pretensos a abolir o regime escravocrata. Além do conceito de "negro", também é utilizado "mulato" como figura da escravidão.

Por fim, o livro "Projeto Pitanguá" contextualiza a questão racial com o sistema de cotas implantado nas universidades públicas atualmente. Não se posiciona claramente sobre a questão, se atendo apenas a justificá-lo como garantia de igualdade de direitos fixada na Constituição Federal. Apresenta opiniões alheias sobre a política, com dois argumentos a favor e um argumento contra.

De acordo com a análise feita, "Projeto Pitanguá" corrobora com a visão segmentária sobre o negro, de que seu papel como escravo contribuiu tão e somente para inferiorizar sua identidade étnico-racial diante dos parâmetros lusíadas de conquista territorial. Além de não tratar da riqueza cultural do povo africano, sua apreciação crítica a respeito da escravidão empobrece o sentido da libertação escravista.

Ainda que esta libertação tenha servido como um marco burocrático e legal para a realeza portuguesa, é a partir daí que os territórios quilombolas tomam forma enquanto espaços de refúgio, e mais ainda, como espaços de revolta política contra a dominação portuguesa. Não só para os escravos fugidos, ex-escravos em situação de miséria, como também para outros segmentos desfavorecidos do sistema instituído, entre eles os indígenas e brancos sem posses.

O livro também não permite a permeabilidade cultural entre os povos africano e português, destacando tão somente os saberes da metrópole européia transportada como mercadoria para o Brasil. A peculiaridade do "ser negro" se limita à visualização do trabalho braçal percebido durante o sistema escravista e após dele sua completa marginalização nas cidades. O negro deixa de ser visto como um escravo pleno para ser visto como escravo de sua própria sorte. 
As duas únicas imagens positivas coletadas foram de uma mulher negra lecionando em sala de aula e outra de uma criança dialogando a respeito dos direitos sociais previstos na Constituição Federal. São centro e trinta e seis páginas, com apenas trezes delas que constam relatos históricos sobre a escravidão, miséria do povo negro contra duas imagens positivas.

O segundo livro analisado, Descobrindo a história, de Sônia Mozer e Vera Telles, da editora Ática, edição de 2007. A temática racial é abordada em 10 capítulos em um total de 16. Já no primeiro capítulo da primeira unidade de ensino, chamado "Um olhar sobre a cidade e o campo", encontra-se a problematização da desigualdade social nas cidades - ainda que não se faça referência à desigualdade racial propriamente dita -, percebe-se a preocupação em expor as relações raciais encontradas no meio urbano, enquanto grupo oprimido e desfavorecido entre os habitantes.

Sob a referência de escravos de ganho, o livro intitula certa imagem em que negros trabalhavam nas ruas para encomendas dos senhores de engenho. Ainda assim, depreende-se da leitura que a vida nas cidades oferecia mais oportunidades aos negros do que no meio rural. No entanto, de acordo com as estimativas publicadas, apenas $2 \%$ da população escrava conquistavam a carta de alforria, explicitadas ainda as condições precárias pelas quais os libertos passavam.

O mesmo capítulo socializa a violência contra a mulher de origem africana, trazendo relatos de cronistas e viajantes que possuíam o universo feminino escravo para prostituição. É afirmado que esse trato subjugado com as negras oprimidas muitas vezes dava fruto a gravidezes indesejadas. Mesmo que a pesquisa em tela não tenha explorado o recorte de gênero, é apropriado observar que as temáticas de gênero e raça estão intimamente relacionadas, tanto que dentro das pesquisas feministas há a preocupação de lançar olhares especialmente acurados à mulher negra.

São trazidas reflexões como uma carta fictícia de uma professora suíça que haveria mudado para o Brasil. O assunto do negro é fomentado em alguns deles, colocando a questão do trabalho manual ser considerado desvalorizado e então classificado função dos escravos. Continuando a explorar o trabalho como categoria essencial à vida dos escravos, as autoras descrevem o dia-a-dia dos escravos e sua jornada de trabalho árdua que freqüentemente ultrapassava dezessete horas diárias.

Neste mesmo contexto trabalhou-se a identidade cultural dos negros enquanto trabalhavam. Com o ritmo musical, os escravos encontravam espaço para disputar pelo diálogo na terra, entre críticas aos senhores de engenho e melodias simplesmente dedicadas à 
memória da cultura africana. Acerca desta memória percebeu-se a ausência de caracteres religiosos advindos com a personificação africana. Este caminho poderia ter sido explorado também pela crítica da injeção religiosa feita pelas escolas jesuítas no período do Brasil Colônia.

A história do Brasil é marcada por conflitos entre o Estado e a Igreja Católica na esfera pública, em que pesa a separação oficial entre essas duas instituições, em 1891, desde quando o país é considerado uma República Federativa. Os reflexos dessa separação para a educação brasileira foram contraditórios: ao mesmo tempo em que a educação se tornava laica, a Igreja Católica introduzia a concepção de educação religiosa na esfera oficial de ensino. Além disso, a religião ainda tinha poder ideológico sobre o Estado, prova disto é o sucesso da educação religiosa nas escolas públicas, representando um apoio institucional entre o Estado e a Igreja na esfera pública de ensino (VIEIRA, 2009).

De acordo com a pesquisa realizada pode-se perceber que as religiões e seitas de matriz africana são amplamente esquecidas no meio escolar, até mesmo no estado da Bahia em que pesa o ensino confessional católico. A universalidade da liberdade de crença constitui inestimável conquista social, que cumpre papel essencial para a legitimidade das religiões e seitas na vida humana, especialmente àquelas que não abraçam valores éticos e morais cristãos.

Outra informação a ser essencial para a desconstrução das estimas conservadoras em torno da histórica luta dos escravos africanos é a contextualização das habitações que não eram formalizadas apenas pelas senzalas. Discute-se a constituição de famílias negras e mesmo o cultivo de própria roça como a tal residência dos senhores.

No segundo capítulo: "De colônia a nação", a disputa entre portugueses e brasileiros na Bahia é posta em foco. A partir desse escrito que aparece a primeira imagem considerada positiva sobre o negro: uma família negra constituída de pai, mãe e dois filhos em cores festivas para comemorar o 2 de Julho, considerado o Dia da Independência na Bahia.

Acerca do processo de Independência, estimula-se o pensamento de que o regime escravocrata foi mantido pelo maior poder de decisão na sociedade, constituído na época pelos grandes fazendeiros. O regime republicano, em contraste com o regime monárquico, poderia trazer maiores prejuízos aos fazendeiros já que apoiava a ampliação da participação popular nos processos de decisão política.

No capítulo seguinte: “Os problemas do Primeiro Reinado", a temática racial é polemizada apenas em uma página, em que se destaca o temor das elites brasileiras em 
relação às rebeliões de escravos. Com a independência do Haiti em voga, as revoltas tornaram-se mais claras e impetuosas. A partir de 1804 as referências de luta haitiana exemplificaram-se por meio de canções. Interessante que a abordagem textual demonstra a resistência negra como exemplo da luta do povo negro no Brasil, que como no Haiti, também foi escravizado.

Cabe ressaltar que ao cabo de cada capítulo há uma seção de exercícios denominada "Verificando o conhecimento". Em relação ao terceiro capítulo notou-se a inclusão da discussão da liberdade de expressão referente ao período imperial. A língua escrava, como coloca o exercício, publiciza a notória ausência de liberdade de manifestação cultural e opinião nessa realidade histórica.

Poderia ter sido continuamente explorado o tema ao longo do livro, levando-se em conta que a formação da língua portuguesa implica palavras e termos originalmente advindos de locais do continente africano. Mais interessante ainda seria contextualizar tal vocabulário com seus costumes religiosos, musicais, gêneros alimentícios.

No capítulo 5: "Rebeliões nas Províncias", Os levantes de escravos da Bahia e a Revolta dos Malês marcam uma rica interpretação sobre o ativismo negro nas rebeliões contra o Poder Imperial a partir da primeira década do século XIX. Em 1807 metade da população da cidade de Salvador - que somava a época cerca de cento e cinqüenta mil habitantes - era constituída por pessoas de origem africana (Mozer \& Telles, 2007).

Não só considerando o desafio da fuga de escravos pelo território baiano com planos de retorno ao continente africano, esse subtítulo possibilita a compreensão do unido povo africano, marcado pelas diferenças religiosas e étnicas, na luta pela liberdade de expressão em um contexto de violência e de agressão. A revolta dos Malês em 1835, por exemplo, foi constituída por escravos e libertos das mais diversas etnias. Indo mais além, esse capítulo especifica outros grupos étnicos dos negros de origem africana como os minas, calabares, tapas, mundubis, jejes, nagôs e gauçás.

O capítulo sétimo da segunda unidade de ensino, intitulado "Escravos e imigrantes, trabalhadores do Império", inicia desconstruindo a ideologia de que a escravidão não mais perfaz nosso cotidiano atual. Denominada escravidão por dívida, o empregador obriga os trabalhadores a pagar por transporte e ferramentas, criando assim uma dívida que nunca é paga (Mozer \& Telles, 2007).

Poderia supor então uma espécie de recolonização simbólica do povo negro? Tal afirmação torna-se perigosa se vista do caminho jurídico percorrido desde a escravidão 
formal, no entanto, vista do caminho da reprodução dos valores discriminatórios presentes na sociedade atual, não seria descabido ao menos discutir tal análise no campo das ciências humanas. Sendo assim, a introdução do capítulo permite o brainstorm $^{5}$ do sistema trabalhista atual em que pesam fatores de desproteção social à parte da população negra do país.

Em relação às imagens fornecidas neste capítulo, podem-se inferir apreciações críticas sobre o valor do negro na sociedade colonizadora. Primeiro porque não podiam usar sapatos, não podiam resgatar o dinheiro que ganhavam como escravos de ganho, ou seja, trabalhavam em ofícios de barbeiros, quitandeiras, de gás, mas não se podia empregá-los para suas necessidades humanas básicas próprias, como alimentação, educação, habitação. Segundo porque as imagens retratam a ausência do direito dos escravos em usar sapatos.

A pauta do tráfico negreiro coloca em questão o papel do negro na transformação do trabalho escravo para o trabalho assalariado, sobre a qual a Inglaterra teve particular interesse. Potência mundial da época, o país estava passando por mudanças econômicas e industriais ensurdecedoras, a chamada Revolução Industrial que revolucionou o conceito de trabalho em grande escala, atingindo não só as potências mundiais como também suas colônias. No entanto, Portugal insistia em manter o tráfico negreiro devido ao seu alto lucro de importação para a colônia brasileira.

Sob efeito da pressão contínua da potência inglesa, em 1831 promulgou uma lei que "extinguia" o tráfico, amplamente conhecida como a lei "para inglês ver". Depreende-se da leitura que esta lei coagiu para que os interesses da Inglaterra fossem mantidos ao menos legalmente. À época este país era considerado a grande potência mundial, e por isso, não poderia ser contrariada pela minoria política, no caso - Portugal.

Cabe assinalar que os interesses de mercado mantido por Portugal e a colônia que posteriormente seria formalmente intitulada como Brasil, não poderiam ser deixados de lado, e por isso internamente os júris locais passaram a ser percebidos pelos proprietários de terra como alvos de corrupção e barganha políticas. O livro mostra que a diminuição do tráfico internacional de negros só aconteceu de fato com a aprovação da lei britânica Bill Aberdeen, lei que permitia aos ingleses de invadir águas territoriais e portos brasileiros para apreender navios negreiros.

Cabe, entretanto, à Lei Eusébio de Queirós aprovada em setembro de 1850 provocar a diminuição de 54 mil em 1849 para 23 mil em 1850, 3 mil em 1851 e apenas setecentos em

\footnotetext{
5 Termo emprestado do inglês ("tempestade de idéias") utilizado normalmente nas áreas de relações humanas e publicidade.
} 
1852. A preocupação do poder político da época não se tratava de melhorar as condições de vida dos ex-escravos, mas sim seguir o ordenamento jurídico das potências mundiais que percebiam o tráfico negreiro como núcleo impedidor da introdução de produtos industrializados do comércio exterior.

Acerca das crenças e cultos africanos Sônia Mozer e Vera Telles novamente retratam a resistência cultural dos negros, que mesmo em condições de vida e trabalho precárias encontravam meios de perpetuar suas concepções culturais e práticas religiosas próprias. Através das roupas brancas de algodão, a imagem de três orixás ${ }^{6}$ retrata a manutenção dos rituais afro-brasileiros em confronto com o catolicismo.

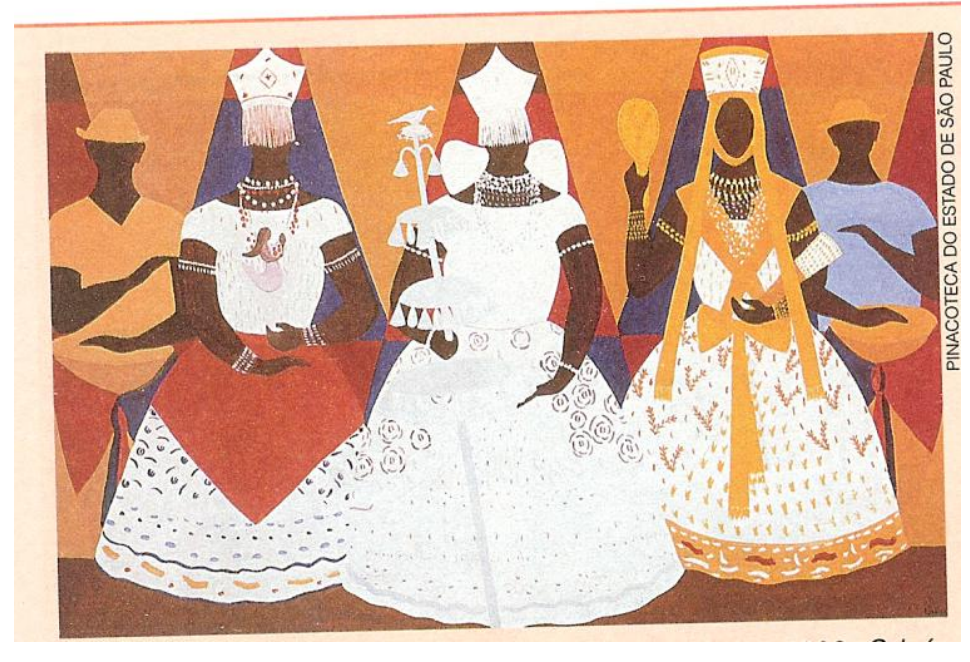

O sincretismo religioso ${ }^{7}$ das religiões afro-brasileiras e a liturgia católica visto hoje nas manifestações religiosas da Bahia trazem à tona esse confronto. Ainda hoje se percebe que algumas seitas evangélicas procuram violentar tais tradições, tal como a manipulação das baianas pela conversão a roupas ocidentalizadas. Conhecida como Bárbara ou Yansã, padroeira dos bombeiros, descendentes de escravos, é um exemplo dessa união forçada dos grupos étnicos africanos ao catolicismo trazido pelos jesuítas de Portugal.

O livro é explicativo quando coloca a definição de candomblé - freqüentado por negros e brancos em busca de revelações, e quando orienta a concepção e diferenciação da cor branca para alguns grupos étnicos da África (nagôs, jejes, angolas). As facetas da capital do

\footnotetext{
6 Divindades africanas presentes em religiões afro-brasileiras como o candomblé. Ao chegarem ao Brasil, os escravos eram obrigados a adotar a religião católica. Muitos procuravam resistir a essa imposição, preservando suas tradições religiosas (MOZER \& TELLES, p. 109).

7 Entende-se por sincretismo religioso a fusão de elementos culturais diferentes e até antagônicos, em um só elemento, continuando perceptíveis alguns traços originários.
} 
Império são trazidas no livro com a percepção crítica da desigualdade social encontrada na cidade do Rio de Janeiro. Em nível de polaridade, a elite brasileira se via bem pouco numerosa de um lado, enquanto era sustentada do outro lado pelos escravos domésticos e escravos de ganho. Mesmo os libertos que tinham condições de vida melhores, ainda viviam desumanamente em locais habitacionais conhecidos como cortiços, controlados pela Família Real.

Para se obter o mínimo das condições de higiene aceitáveis na época as famílias pobres e negras pagavam um aluguel. As que não tinham condições de pagar nem o mínimo do aluguel começaram a se instalar em barracos nos morros ou nas áreas alagadiças da cidade. Para que não se pense que as comunidades existentes hoje no Rio de Janeiro surgiram pelo descaso das autoridades em conter o superpovoamento dos morros em condições ambientalmente incorretas, inicialmente estas habitações eram vistas como mercado para a elite ganhar dinheiro à custa da maioria negra.

Convém refletir acerca da exclusão das etnias negras no processo de urbanização. As políticas de habitação freqüentemente figuraram o zoneamento, ou seja, delimitando usos para certas áreas brasileiras como as conhecidas comunidades do Rio de Janeiro. O preconceito cultural, que figura-se em exclusões sociais, figura também exclusões espaciais? As etnias negras foram marginalizadas dos centros e das próprias cidades? As cidades, que provém todo um aparato social são cidades para essas etnias? No entanto, o livro "Descobrindo a História Brasil Independente" se limita a narrativa histórica da questão habitacional vivenciada pela população escrava da época.

Cabe ressaltar que constantemente a obra procura problematizar a resistência cultural africana por meio da desigualdade racial inferida na desigualdade de classes sociais presente no Império. Os confrontos da vivência urbana e rural também se perfazem por imagens, em que as relações de mando e obediência na cafeicultura escravista se encontram em constante desarmonia.

Em contrapartida, as amas-de-leite supostamente desenvolviam relações de afeto com as crianças libertas, ao menos de acordo com a obra didática. 


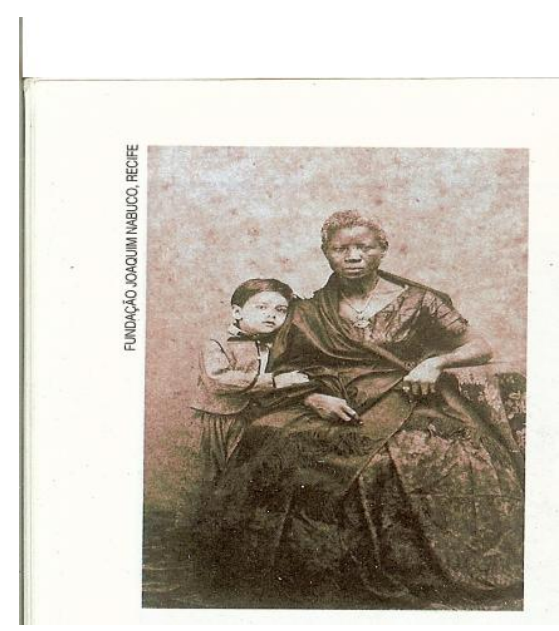

Sendo ou não assim, é posto o mercado de amas-de-leite como rendoso e bastante prático para os senhores de escravos. As mulheres brancas e livres aderiam a tal comércio até que notícias do velho continente puderam despertar a ideologia cultural através do aleitamento materno. Seguindo esta lógica, visto que não fosse interessante perpetuar valores e tradições culturais africanas para as crianças, melhor que cultivassem esta aproximação com a criança.

Diante da peculiaridade da criança escrava, o livro retrata o destino previsível das crianças negras que praticavam a educação simplesmente para o trabalho. A imagem de uma criança sendo castigada por uma mulher branca, no entanto, deixa clara somente a submissão de ordens aos membros da elite.

A provocação de temas culturais advindos das camadas populares torna-se constante: literatura, sons, ritmos e festas religiosas são permeados pela história afro-brasileira e indígena, e quando não, com a polêmica de sua existência desde os tempos de Brasil Império. Exemplos dos gêneros literários modinha e $l u n d u$, os ritmos do batuque e o ativismo musical de Chiquinha Gonzaga (1847-1935) se tornam essenciais para o contexto da libertação dos escravos, não tão pouco somente dos senhores de engenho como principalmente da ditadura cultural silenciosamente implantada aos moldes europeus de vivência cotidiana.

Segunda unidade de ensino, capítulo 11 sobre a "Libertação dos Escravos". Comenta a realidade da pós-escravatura e de que forma a desigualdade racial permeia a sociedade brasileira nos dias atuais. Não são citadas diretamente políticas de ação afirmativa voltadas para a população negra, mas cabe reiterar a preocupação que o livro traz sobre a ausência do povo negro nas políticas sociais como saúde, educação e trabalho.

O destaque, no entanto, se deve ao reforço das autoras em destacar o significado de todas as pautas políticas até a sanção da Lei Áurea no dia 13 de maio de 1988. Seguindo a 
ordem cronológica dos fatos que levaram ao "fim" do regime escravocrata, o texto depõe críticas sobre o interesse político em abolir tal regime, de tal forma que as elites se dividiam entre os abolicionistas pró-revolucionários e pró-conservadores.

$\mathrm{Na}$ verdade, todo o processo para que se chegasse à conquista da liberdade além da letra da lei haveria se der decidido por pressões políticas. Fazendeiros exerciam seu papel de defender a "propriedade privada", propriamente os cativos da terra, enquanto o declínio do tráfico negreiro influenciava diretamente no corte de trabalho rendoso e escravo para os senhores de engenho. Enfim, sobre a temática da libertação dos escravos o livro procura demonstrar que apesar de não obter muitos ganhos com as medidas abolicionistas, os escravos foram ativistas de sua própria história nos entrementes da abolição, que resultariam na prática em uma maior visibilidade das polêmicas que geraram a escravidão no Brasil.

Este capítulo propôs uma leitura dinâmica do preconceito racial na contemporaneidade, a partir da realidade pós-escravidão na sociedade brasileira até os dias atuais. O questionamento formulado é: "Qual a distância entre a letra da lei e a aplicação da cidadania para os negros neste país?”. Não cabendo responder, mas sim instigar reflexões dos estudantes, é posto um poema satírico publicado no jornal $O$ monitor Campista publicado em 1888 sobre a visão de alguns fazendeiros sobre o ex-escravo.

Fui ver os pretos na cidade

Que quisessem se alugar.

Falei com humildade:

- Negros, querem trabalhar?

Olharam-me, de soslaio,

E um deles, feio, cambaio,

Respondeu-me, arfando o peito:

"Negro não há mais não

Nós tudo hoje é cidadão

O branco que vá pro eito".

Extraído de: Sonia Mozer e Vera Telles. Obra citada, p.134.

Há também exercícios sobre a Lei do Ventre Livre e a visão do povo em confronto com a visão dos intelectuais sobre o abolicionismo da escravidão. Ainda é proposto a 
realização de debates em sala de aula sobre dois temas: $1^{\circ}$ ) Ser negro no Brasil, no século XXI e $2^{\circ}$ ) O negro e a Constituição de 1988.

Por último, o capítulo 16 da terceira unidade contextualiza sobre os Movimentos Populares na Primeira República. Dentre os movimentos discutidos está a Revolta da Chibata repercutida no Rio de Janeiro, em 1910. A injeção cultural da escravidão nos costumes da Marinha brasileira é interpretada a partir da rebelião liderada por João Cândido, ou mais conhecido como Almirante Negro. Além disso, colocou-se uma imagem do grupo de marinheiros negros que compunham a revolta.

O terceiro livro didático analisado - Saber e fazer história -, é de autoria de Gilberto Cotrim, editora Saraiva, edição de 2006. A obra didática fora elaborada para a $7^{\mathrm{a}}$ série do ensino fundamental, atualmente denominado $8^{\circ}$ ano. De 16 capítulos, o livro contém apenas 4 capítulos que discutem o tema analisado.

Continuando o objetivo-sistemático desta pesquisa de relacionar os dados históricos e sócio-culturais da África com a nação brasileira, ao mesmo tempo atentou-se a todo conteúdo presente sobre escravismo e populações oprimidas. O primeiro destaque do livro referente ao assunto é sobre o processo de independência do Haiti reconhecido em 1825. Sob o enfoque dos movimentos populares engrenados pelos haitianos, o livro permite a análise do controle social realizado pelas elites e pela qual a repressão acontece na maior parte das regiões da América Latina.

Próximo capítulo do livro, o capítulo 9 trata da "Independência política do Brasil". Desde a situação colonial permeada no século XVI até o início do século XIX, encontra-se a categorização dos colonizadores, colonizados e colonos. De acordo com os dados, mais de $80 \%$ da população no final do século XVII é categorizada em colonizados, entre eles escravos africanos, grupos indígenas e brancos livres e pobres.

Não há a preocupação em considerar os escravos fundamentalmente como integrantes da diversidade humana e pertencentes à raça socialmente construída negra. Ou seja, percebeuse a ausência de imagens positivas sobre o negro, enquanto mesmo economicamente desfavorecido, o branco ainda é visto como um ser livre e trabalhador assalariado.

Em seguida trata-se das rebeliões ocorridas em toda nação durante a crise colonial. Sobre a Conjuração Baiana ou conhecida também como Revolta dos Alfaiates, o livro coloca seu caráter libertário e revolucionário para estabelecer a independência política em relação Portugal. Destaca, no entanto, que concretizou mais um interesse de independência regional do que nacional. Seria um bom momento para explorar o africanismo na Bahia, e seu apelo 
contra a escravidão sendo diferente da maioria das outras revoltas no centro-sul, nas quais não era interessante reivindicar a abolição do regime escravocrata.

No capítulo 11: "Expansão do Imperialismo", ocorre à contextualização do neocolonialismo do século XIX como meio das potências mundiais da época difundir "o dito progresso econômico e cultural”. Afirma-se de forma crítica essa expansão colonial, embutidos os elementos religiosos, imperiosidade da raça branca, desenvolvimento científico e tecnológico da Revolução Industrial nas idéias preconceituosas, racistas e de superioridade cultural, criaram-se argumentos para justificar a exploração brutal de diferentes povos africanos e asiáticos (COTRIM, 2006).

O tema da partilha do continente africano é explanado rapidamente, apenas citando a Conferência de Berlim de 1884 a 1885 e a guerra dos bôeres ocorrida na África do Sul em torno da extração dos diamantes e de ouro. Ainda é questionada a construção do Império Francês em alguns países africanos como Senegal, Argélia e Costa do Marfim, dividindo assim o continente em África Ocidental Francesa e África Equatorial Francesa.

O capítulo 13: "O Brasil: o jogo político no Primeiro Reinado" destaca claramente a exclusão perpetuada no primeiro processo constitucional em 1824. A parte dos grandes fazendeiros, a grande maioria da população - negra, mulher, comerciantes -, não tinha acesso aos direitos estabelecidos em questão.

Outro debate promovido questiona as revoltas provinciais ocorridas em todo o país, e em grande medida, a opressão dos poderosos e o isolamento que afetava as populações mais pobres do país. Seguindo essa linha de raciocínio, é posta a predominância das elites para o pensamento liberal da época. Em um artigo à parte, explica-se a função de uma Constituição em garantir a liberdade e igualdade de todos mesmo que a realidade não demonstrasse que a lei fosse legítima para a população negra. Poderia ter sido mais explorada a questão da resistência negra, fomentando o debate sobre o negro não reproduzir o molde escravocrata passivamente, mas sim lutando contra toda forma de opressão e repressão aos escravos e libertos.

Em geral, as imagens do livro: Saber e fazer história - História Geral e do Brasil (Consolidação do Capitalismo e Brasil Império) reproduzem o significado da opressão dos colonizadores perante o negro, sendo comum, por exemplo, imagens de negras vendedoras de doces e refrescos, escravos acorrentados para evitar a fuga e mulheres negras no mercado. 


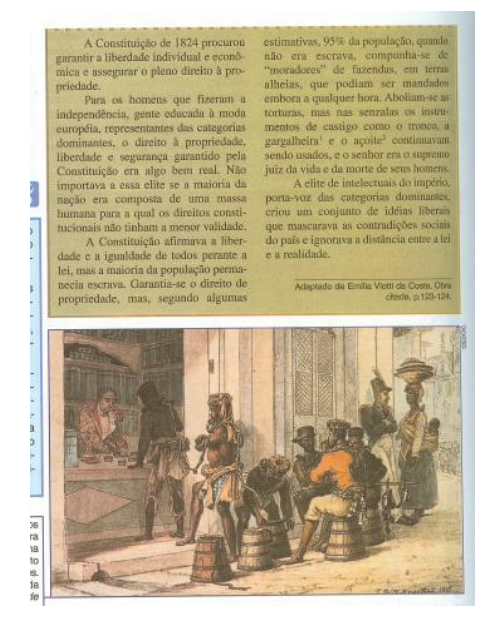

Poderia não ter se limitado ao papel do negro lutando capoeira, explorando outros ritmos africanos como o fez o livro Descobrindo a História - Brasil Independente, e aflorando as diferenças dos grupos étnicos aportados no território brasileiro.

Igualmente, implica-se que a missão civilizadora de propagar o catolicismo como religião única e legítima do Brasil Colônia e Brasil Império não foi suficiente para corromper a propagação cultural dos diferentes grupos étnicos africanos. Os alicerces para a visão ampla da cultura africana precisavam ir além do simples poder do catolicismo em destruir suas bases sem deixar possibilidades de compensações.

Considerando que o referencial epistemológico do Brasil ainda seja europeu, torna-se fundamental que nas escolas atuem livros didáticos que não tratem a obrigatoriedade da inclusão da temática da cultura afro-brasileira como o menor índice de conteúdo já tratado de forma pontual e no mínimo, conservadora: os temas religiosos e culturais africanos foram destruídos pela Igreja Católica resultando na ausência de sinais de resistência negra para a formação da sociedade brasileira.

Imagens contendo o juramento da Constituição pela princesa Isabel, a assinatura da Lei Áurea podem contribuir para a visão destorcida de que os brancos conquistaram o abolicionismo da escravidão, tornando possível o "sonho" de liberdade para o negro. A Lei Áurea representa uma arena para a luta da campanha abolicionista, mas também representa os interesses de manutenção da escravidão em prol dos politicamente favorecidos fazendeiros. $\mathrm{O}$ movimento negro foi o responsável pela ressignificação desta data, passando a ser uma data de denúncia contra o racismo.

A ressignificação da história do povo africano está diretamente relacionada a abordagem das obras didáticas. Conteúdos racistas não contribuem para a discussão sobre a 
discriminação racial e menos ainda contribuem para a percepção da cultura negra pelos estudantes.

Por fim a obra Construindo consciências, de Leonel Itaussu de A. Mello e Luís César Amad Costa, editora Scipione, edição de 2008. O último livro contém 19 capítulos e discute em apenas dois capítulos a temática racial. Primeiramente no capítulo 5: "Os conflitos sociais no início da República no Brasil” e depois no décimo segundo capítulo: “A descolonização da Ásia e da África (1945-1975).

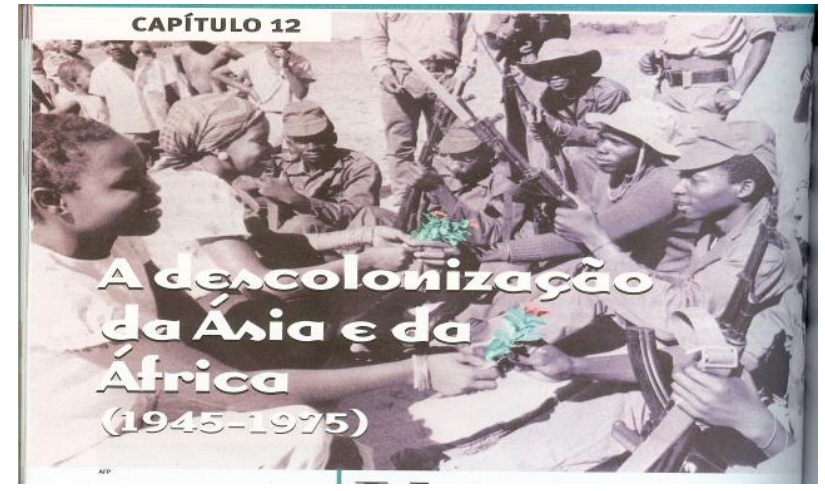

Sob o contexto da Revolta da Chibata, o conteúdo expressa a resistência negra após vinte anos da abolição de forma contundente. Esclarece a relação do negro com a Marinha brasileira na época por meios da política da brutalidade física, estando os companheiros negros unidos contra os castigos corporais e as más condições de trabalho (FIGURA 8). Vale ressaltar que o ano de 2010 foi o centenário da Revolta e no Brasil aconteceram várias homenagens ao Almirante Negro, inclusive com a construção de um navio que recebeu seu nome.

No capítulo décimo segundo a questão racial é discutida por meio do novo imperialismo do século XIX. O capítulo começa a traçar o caminho de independência de países asiáticos como Índia e Indonésia. Depois problematiza o continente africano especificando as guerras civis ocorridas em cada país, entre eles Argélia, Congo, Moçambique, Guiné-Bissau, Angola e Cabo Verde.

O livro mostra que apesar de todas as guerras terem resultado no reconhecimento do país colonizador de sua independência, o caminho percorrido pelas colônias resultou em milhares de centenas de feridos e mortos, que se não bastassem, continuam a ocorrer até hoje devido à partilha geográfica desconsiderando os grupos étnicos africanos.

Sobre os dias atuais a obra didática revela novamente o que a mídia constantemente veicula sobre o continente africano: pobreza e Aids. Fornecendo dados escandalosos da 
doença no continente, o caminho encontrado como solução é o perdão da dívida dos países "subdesenvolvidos". No entanto, não se vincula tal "perdão" a um esforço mínimo das potências mundiais em reconhecerem suas faltas graves com a preservação cultural e territorial dos grupos étnicos africanos. Não se discute o desrespeito aos direitos humanos cometido pelo poderio europeu, mas sim uma possível benignidade perante os países "subdesenvolvidos". Por fim, o livro poderia trazer exercícios que problematizam o significado das datas e a singularidade que representaram a manifestação histórica contra a escravidão.

Sabendo que o livro didático por muitas vezes é o único instrumento de ensino, deveria ser utilizado em prol da ressignificação da história dos negros no Brasil e não continuar servindo para perpetuar conteúdos banalizados e sem embasamento teórico. 


\section{Considerações Finais}

Esta pesquisa polemizou sobre a abordagem racial nos livros didáticos aprovados pelo MEC e utilizados nas escolas públicas de ensino fundamental, a partir da sanção da Lei $10.639 / 2003$.

A discussão trabalhada tornou-se imperativa, visto que o campo teórico voltado para a temática racial relacionada à educação é vista como incipiente, sem falar na ausência de estudos voltados para a análise do real significado da educação para o segmento negro. A perspectiva libertária desta pesquisa procurou possibilitar uma maior divulgação da questão racial nos livros didáticos.

Torna-se imprescindível que a percepção crítica das obras seja percebida com a formação de professores para a temática, já que a transmissão eficiente do conteúdo depende de sua coerência com a prática de ensino, ou seja, não apenas repassando o conteúdo de forma unilateral, mas também contribuindo para a participação dos estudantes no processo de ensino-aprendizagem. O livro didático possui dimensão social, pedagógica e dinâmica, as quais devem ser potencializadas constantemente, por professores, estudantes e pelos movimentos negros, os quais foram e são responsáveis pela discussão sócio-política da educação anti-racista.

Nosso estudo interrompeu com o silêncio sobre o assunto na universidade e também permitiu o despertar interesse acerca do processo de implementação da Lei 10.639/2003 no ambiente escolar a partir da análise documental. A análise do conteúdo abordado em sala de aula é um ponto de partida essencial para a compreensão do universo de possibilidades para os estudantes, principalmente negros, refletirem sobre a percepção de sua auto-estima enquanto descendentes da cultura negra no Brasil.

O silêncio sobre as trajetórias positivas do negro na história pode significar o silêncio sobre o envolvimento com a raça negra, enquanto o equilíbrio da influência européia não for polemizado pela importância do africanismo na formação da sociedade brasileira. Não foi surpreendente constatar que o espaço do conhecimento é uma disputa de discursos ideológicos pela hegemonia da aceitação da maioria.

Ou seja, não se refere a uma simples questão de reconhecimento da própria raça negra sobre a memória de seus antepassados, até porque a população brasileira já tem acesso a referenciais epistemológicos que afirmem sua identidade cultural. Em contrapartida, tais 
referenciais não reforçam a identidade cultural negra de forma ampla e positiva na sociedade. Para isso o imaginário social deveria encontrar formas construtivas de conhecimento baseados em uma percepção crítica da importância do negro para a formação do Brasil como nação.

Em contrapartida, as principais abordagens da questão racial encontradas nos livros didáticos trazem possibilidades para o debate sobre o racismo no espaço escolar a partir da pesquisa documental. Mesmo diante da conjuntura negativa percebida, o livro didático, enquanto instrumento metodológico para o processo de ensino-aprendizagem continua sendo essencial para a desconstrução da discriminação racial e para a compreensão das diferenças raciais no espaço escolar, sendo na maioria o único instrumento de ensino dos profissionais de educação.

Por outro lado, não se pode deixar de polemizar a contínua existência do racismo institucional nas escolas, pela qual o vínculo da obrigatoriedade da legislação acerca da cultura afro-brasileira se torna prejudicado. Em se tratando da representação social da aplicação legal incitada, os sujeitos envolvidos na dinâmica escolar são essenciais, à medida que correspondem à eficácia do embasamento teórico construído para tal.

Por isso é fundamental que o Projeto de Lei ${ }^{\circ}$ 60/2007 seja aprovado no Congresso Nacional. A inserção dos profissionais de Serviço Social e Psicologia certamente trarão frutos da conciliação do saber e da igualdade racial, pois compartilham no âmago de sua formação a promoção da pluralidade.

Igual necessidade tem a articulação entre universidade, movimentos sociais e escolas, já polemizado no segundo termo do artigo 23 do Estatuto de Igualdade Racial: “O Ministério da Educação fica autorizado a incentivar as instituições de ensino superior, públicas e privadas a incorporar nas matrizes curriculares dos cursos de formação de professores temas que incluam valores respeitantes à pluralidade étnica e cultural da sociedade brasileira. Além disso, a formação superior deve tratar as relações raciais em seus currículos oficiais.

Por fim, este TCC foi pensado como aprofundamento e sistematização do conhecimento adquirido ao longo do curso de Serviço Social. Considerando a profissão escolhida generalista de sua gênese, não há como desvencilhar a relação do Serviço Social com a temática étnico-racial. 


\section{REFERÊNCIAS BIBLIOGRÁFICAS}

ABRAMOVAY, Miriam. et al. Revelando tramas, descobrindo segredos: violência e convivência nas escolas. Brasília: Rede de Informação Tecnológica Latino-Americana RITLA, Secretaria de Estado de Educação do Distrito Federal - SEEDF, 2009.

APPLE, Michael W. Para além da lógica do mercado. Compreendo e opondo-se ao Neoliberalismo. Rio de Janeiro: DP \& A Editora, 2005, p. 07-58.

BAUER, Martin \& GASKELL, George. Pesquisa qualitativa com texto: imagem e som: um manual prático. Petrópolis, RJ: Vozes, 2008.

BARBOSA, Maria Lígia de O., "Capítulo 1: As relações entre Educação e Raça no Brasil: um objeto em construção", in: SOARES, Sergei ET alii (orgs.), Os mecanismos de discriminação racial nas escolas brasileiras. Rio de Janeiro: IPEA, 2005, p. 05-19.

BONI, Valdete \& QUARESMA, Silvia Jurema. Aprendendo a entrevistar: como fazer entrevistas em Ciências Sociais. Revista Eletrônica dos Pós-Graduandos em Sociologia Política da UFSC. Santa Catarina: 2005, Vol. 2 no 1 (3), janeiro-julho/2005, p. 68-80, Disponível: http://www.emtese.ufsc.br/3_art5.pdf. Acesso em: outubro de 2010.

BRASIL. Constituição da República Federativa do Brasil. Brasília: Senado Federal, 1988.

BRASIL, Lei $n^{o} 7.716 / 1989$. Define os crimes resultantes de preconceito de raça ou de cor. Brasília, 1989.

BRASIL, Lei $n^{\circ}$ 9.459/1997. Altera os arts. $1^{\circ}$ e 20 da Lei $n^{\circ} 7.716$, de 5 de janeiro de 1989, que define os crimes resultantes de preconceito de raça ou de cor, e acrescenta parágrafo ao art. 140 do Decreto-lei n 2.848 , de 7 de dezembro de 1940.

BRASIL. Lei $n^{o}$ 10.639/2003. Dispõe sobre a obrigatoriedade do ensino de história e cultura africana nas escolas públicas. Brasília, 2003.

BRASIL. Lei $n^{o}$ 11.645/2008. Dispõe sobre a inserção do conteúdo de tradições indígenas no currículo escolar das escolas públicas. Brasília, 2008.

BRASIL, Lei $n^{\circ}$ 12.288/2010. Institui o Estatuto de Igualdade Racial e altera Leis $\mathrm{n}^{\mathrm{os}}$ 7.716, de 5 de janeiro de 1989, 9.029, de 13 de abril de 1995, 7.347, de 24 de julho de 1985, e 10.778, de 24 de novembro de 2003. Brasília, 2010.

BRASIL. Parecer do Conselho Nacional de Educação $n^{o} 003$ de 2004. Discute as Diretrizes Curriculares Nacionais para a educação das Relações Étnico-Raciais e para o Ensino de História e Cultura Afro-Brasileira e Africana. Brasília, 2004. 
BRASIL. Resolução do Conselho Nacional de Educação $n^{\circ} 001$ de 2004. Institui Diretrizes Curriculares Nacionais para a educação das Relações Étnico-Raciais e para o Ensino de História e Cultura Afro-Brasileira e Africana. Brasília, 2004.

CASTEL, Robert. A discriminação negativa: cidadãos ou autóctones? Petrópolis, RJ: Vozes, 2008.

CENTRO LATINO-AMERICANO EM SEXUALIDADE E DIREITOS HUMANOS. Gênero e diversidade na escola: formação de professoras/es em gênero, sexualidade, orientação sexual e relações étnico-raciais. Rio de Janeiro: CEPESC; Brasília: SPM, 2009.

CONNELL, Robert W., "Pobreza e Educação", in: GENTILI, Pablo (org.), Pedagogia da exclusão - crítica ao neoliberalismo em educação. Petrópolis/RJ: Vozes, 2002.

COSTA, Ângelo Roger de França. A problemática racial na política de assistência social no Brasil: o desafio da especificidade negra. 2008. 70 f. Monografia (Bacharelado em Serviço Social)-Universidade de Brasília, Brasília, 2008.

COSTA, Sérgio. Sobre o conceito de raça: A construção sociológica da raça no Brasil. Estudos afro-asiáticos, Rio de Janeiro, vol. 24, n. 01, p. 35-61. Disponível em: http://www.cebrap.org.br/v1/upload/biblioteca_virtual/COSTA_A\%20construcao\%20sociolo gica\%20da\%20raca\%20no\%20Brasil.pdf

COTRIM, Gilberto. Saber e fazer história. $7^{\text {a }}$ série. São Paulo: Saraiva, 2002.

FERES JÚNIOR, João, "Aspectos Normativos e Legais das Políticas de Ação Afirmativa", in: FERES JÚNIOR, João \& ZONINSEIN, Jonas (orgs.), Ação Afirmativa e Universidade. Experiências Nacionais Comparadas. Brasília: Editora UnB, 2006, p. 46 - 62.

FERNANDES, Florestan. A integração do negro na sociedade de classes. São Paulo: Ática, 1978. O legado da "Raça Branca". FREIRE, Paulo. Pedagogia do oprimido. Rio de Janeiro: Paz e Terra, 1975.

GUIA DE LIVROS DIDÁTICOS: PNLD 2011: HISTÓRIA. Brasília: Ministério da educação, Secretaria de Educação Básica, 2010.

GUIMARÃES, Antônio Sério Alfredo. Classes, raças e democracia. São Paulo: Editora 34, 2002.

LADSON-BILLINGS, Gloria. Os guardiões de sonhos: o ensino bem-sucedido de crianças afro-americanas. Belo Horizonte: Autêntica Editora, 2008.

LIMA, Juliana Soares. Educação, raça e desigualdade social: uma análise das respostas institucionais da Universidade de Brasília aos estudantes cotistas. 2007. 75 f. Monografia (Bacharelado em Serviço Social)-Universidade de Brasília, Brasília, 2007. 
MELANI, Maria Raquel Apolinário. Projeto Pitanguá: História. $5^{\circ}$ ano. São Paulo: Moderna, 2008.

MELLO, Leonel Itaussu de A. \& COSTA, Luis César Amad. História. $8^{\circ}$ série. Editora Scipione, 2006.

MINISTÉRIO DA EDUCAÇÃO/SECRETARIA DE EDUCAÇÃO CONTINUADA, ALFABETIZAÇÃO E DIVERSIDADE. Orientações e ações para a educação das relações étnico-raciais. Brasília: SECAD, 2010.

MORAES, Kelly da Silva. A lei 10639/03 e seus reflexos nos materiais didáticos: uma análise sobre o negro na história do Brasil. Porto Alegre: FAPA, 2006.

MOZER, Sônia \& TELLES, Vera. Descobrindo a história. 6ª série. São Paulo: Ática, 2007.

MUNANGA, Kabengele. Afinal, o que é a África? Revista Brio, São Paulo, n. 1, 1995.

OLIVA, Anderson Ribeiro. A história africana nas escolas brasileiras: entre o prescrito e o vivido, da legislação educacional aos olhares dos especialistas (1995-2006). História, 2009, vol.28, n. 2, p.143-172. ISSN 0101-9074. Disponível em: http://www.scielo.br/scielo.php?script=sci_arttext\&pid=S0101-90742009000200007\&lng=en\&nrm=iso

OSORIO, Rafael G. \& SOARES, Serguei, "Capítulo 2: A geração 80: Um documentário estatístico sobre a produção das diferenças educacionais entre negros e brancos", in: SOARES, Sergei et alii (orgs.), Os mecanismos de discriminação racial nas escolas brasileiras. Rio de Janeiro: IPEA, 2005, p.21-39.

RIBEIRO, Matilde. A conjuntura brasileira: o Serviço Social posto à prova. As abordagens étnico-raciais no Serviço Social. In: Revista Serviço Social e Sociedade, no 79. Ano XXV, especial. Ed. Cortez. São Paulo. 2004.

SANTOS, Sales Augusto dos. A Lei no 10.639/03 como fruto da luta anti-racista do Movimento Negro. In: Educação anti-racista; caminhos abertos pela Lei Federal $n^{\circ}$ 10.639/03. Brasília: MEC; Secretaria de Educação Continuada, Alfabetização e Diversidade, 2005.

TAQUETTE, Stella R. Aids e juventude: gênero, classe e raça. Rio de Janeiro: EdUERJ, 2009.

VALVERDE, Danielle Oliveira. Para além do ensino médio: a política de cotas da Universidade de Brasília e o lugar do/a jovem negro/a na educação. Dissertação de Mestrado em Educação, Universidade de Brasília, 2008, Orientadora Wivian Weller, 263 páginas. Disponível em: http://bdtd.bce.unb.br/tedesimplificado/tde_busca/arquivo.php?codArquivo=3652

VIEIRA, Clarice. O ensino religioso nas escolas públicas: qual o pluralismo? Relatório de pesquisa apresentado ao projeto de iniciação científica orientado pela Professora Doutora Débora Diniz. Brasília: Universidade de Brasília, 2009 (mimeo). 
VIEIRA, Clarice et al. Projeto político-pedagógico e controle democrático. Prova final apresentada à disciplina Política de Educação ministrada pela Professora Silvia Cristina Yannoulas. Brasília: Universidade de Brasília, 2010. (mimeo)

VIEIRA, Clarice. Quilombos Contemporâneos no Brasil. Trabalho final apresentado à disciplina Pensamento Negro Contemporâneo ministrada pela Professora Deborah Santos. Brasília: Universidade de Brasília, 2008 (mimeo).

ZONINSEIN, Jonas \& FERES JÚNIOR, João, "Introdução - Ação Afirmativa e Desenvolvimento", in: FERES JÚNIOR, João \& ZONINSEIN, Jonas (orgs.), Ação Afirmativa e Universidade. Experiências Nacionais Comparadas. Brasília: Editora UnB, 2006, p. 09-45. 


\section{APÊNDICES}

\section{APÊNDICE I: ROTEIRO DE ENTREVISTA SEMI-ESTRUTURADA}

1. Quais foram as principais referências dos movimentos sociais para o surgimento da Lei $n^{\circ}$. 10639/03?

2. A partir desta iniciativa, como entrevê a atuação desta Instituição para a sanção da mencionada lei?

3. Quais foram as principais reivindicações do movimento negro para o estabelecimento desta legislação?

4. Os livros didáticos conseguem atingir às suas demandas ou se mostram limitados para a propagação da cultura e história afro-brasileira nas escolas?

5. De que forma enxerga a contribuição dos livros didáticos para a promoção da igualdade racial no Brasil?

6. Quais avanços para a política de educação após a implementação da lei? E quais os retrocessos?

7. Sugeriria modificações na estrutura do conteúdo? Se sim, quais seriam? 


\begin{tabular}{|c|c|c|}
\hline $\begin{array}{l}\text { Descobrindo a História: Brasil } \\
\text { Independente }\end{array}$ & $\begin{array}{c}\text { Construindo consciências: } \\
\text { História }\end{array}$ & Análise de dados \\
\hline \multirow[t]{2}{*}{ Cidadania } & Cidadania & $\begin{array}{l}\text { A definição é mais abrangente no } \\
\text { livro de Construindo consciências: } \\
\text { História. O autor descreve o } \\
\text { significado da palavra desde os } \\
\text { tempos gregos em que mulheres } \\
\text { não podiam votar e a inclusão do } \\
\text { voto para a ampliação da cidadania } \\
\text { na sociedade. Já no outro livro a } \\
\text { conceituação se restringe à relação } \\
\text { de direitos e deveres e a } \\
\text { exemplificação de alguns direitos } \\
\text { fundamentais como trabalho, vida, } \\
\text { igualdade. }\end{array}$ \\
\hline & Democracia multiétnica & $\begin{array}{l}\text { Único título que somente o livro } \\
\text { Construindo consciências: História } \\
\text { possui, pode ser relacionado ao } \\
\text { conceito de Identidade Cultural } \\
\text { encontrado no livro de Vera Telles } \\
\text { e Sônia Mozer. Interessante } \\
\text { porque seria como uma } \\
\text { substituição da "democracia } \\
\text { racial" pregada pela ideologia de } \\
\text { Gilberto Freyre. }\end{array}$ \\
\hline Direitos de cidadania & & $\begin{array}{l}\text { Além de complementar o conceito } \\
\text { de cidadania, é dita a ausência do } \\
\text { alcance de cidadania para os } \\
\text { escravos na época do Império. }\end{array}$ \\
\hline Direitos humanos & & $\begin{array}{l}\text { Enfatiza-se a diferença dos direitos } \\
\text { humanos e de cidadania, fazendo a } \\
\text { oposição dos direitos humanos a } \\
\text { qualquer forma de discriminação, } \\
\text { incluída a de raça. }\end{array}$ \\
\hline Genocídio & Genocídio & $\begin{array}{l}\text { O conceito é tratado de forma mais } \\
\text { completa no livro Descobrindo a } \\
\text { História: Brasil Independente, } \\
\text { visto que além do extermínio de } \\
\text { uma raça, povo ou nação há a } \\
\text { visão da matança de pessoas } \\
\text { pobres, ou de crianças, como } \\
\text { consequiência das desigualdades }\end{array}$ \\
\hline
\end{tabular}




\begin{tabular}{|c|l|l|}
\hline Identidade Cultural & sociais. \\
\hline Índice de natalidade & $\begin{array}{l}\text { A referência ao povo negro é feita } \\
\text { em todo onceito, por meio da } \\
\text { manifestação cultural e religiosa } \\
\text { da qual tiveram grande } \\
\text { impedimento do catolicismo para } \\
\text { se manifestar. }\end{array}$ \\
\hline Islamismo & $\begin{array}{l}\text { Outra vez fazendo referência ao } \\
\text { negro, desta vez sobre a polêmica } \\
\text { da baixa natalidade devido às } \\
\text { condições de vida precárias e o } \\
\text { número reduzido de mulheres. }\end{array}$ \\
\hline Orixá & $\begin{array}{l}\text { O livro faz referências a uma das } \\
\text { mais importantes religiões } \\
\text { atualmente, ligando ao fato que no } \\
\text { continente africano se encontram } \\
\text { muitos de seus adeptos. }\end{array}$ \\
\hline & Jazz & $\begin{array}{l}\text { Mesmo que se perceba uma } \\
\text { intenção em descrever um estilo } \\
\text { musical relacionado à população } \\
\text { afro-americana, também pode } \\
\text { reforçar o trato estereotipado do } \\
\text { negro na área musical. }\end{array}$ \\
\hline & $\begin{array}{l}\text { Limita-se a dizer que orixá é a } \\
\text { denominação dada às divindades } \\
\text { nos cultos afro-brasileiros de } \\
\text { origem ioruba. }\end{array}$ \\
\hline & & \\
\hline & &
\end{tabular}




\section{APÊNDICE III: REFERÊNCIAS AO NEGRO NOS LIVROS DIDÁTICOS}

\begin{tabular}{|c|c|c|c|}
\hline $\begin{array}{c}\text { Projeto Pitanguá: } \\
\text { História }\end{array}$ & $\begin{array}{l}\text { Saber e Fazer História: } \\
\text { História Geral e do } \\
\text { Brasil (Consolidação } \\
\text { do Capitalismo e } \\
\text { Brasil Império) }\end{array}$ & $\begin{array}{l}\text { Descobrindo a } \\
\text { História: Brasil } \\
\text { Independente }\end{array}$ & $\begin{array}{c}\text { Construindo } \\
\text { consciências: História }\end{array}$ \\
\hline Escravos & Escravos & Escravos & \multirow[t]{18}{*}{ Negros } \\
\hline Escravos africanos & Escravos africanos & Mulatos & \\
\hline Revoltosos da Bahia & Colonizados & Negros libertos & \\
\hline \multirow[t]{2}{*}{ Mulatos } & Líderes mais pobres & Escravos de ganho & \\
\hline & & Escravos domésticos & \\
\hline Libertos & Líderes mulatos & População escrava & \\
\hline \multirow[t]{12}{*}{ Tigres } & \multirow[t]{12}{*}{ Negros } & $\begin{array}{c}\text { Pessoas de origem } \\
\text { africana }\end{array}$ & \\
\hline & & Quilombolas & \\
\hline & & Cativos & \\
\hline & & Africanos & \\
\hline & & Minas & \\
\hline & & Calabares & \\
\hline & & Tapas & \\
\hline & & Mundubis & \\
\hline & & Jejes & \\
\hline & & Nagôs & \\
\hline & & Hauçás & \\
\hline & & Malês & \\
\hline
\end{tabular}




\section{Anexos}

ANEXO 1: Edital do PNLD 2013

\section{CRITÉRIOS DE EXCLUSÃO}

2.1. Nesta etapa, serão excluídas as obras didáticas que apresentarem as seguintes características, salvo o disposto nos subitens 6.2.1.1 e 6.2.1.2:

A26: Coleções de Ciências, História e Geografia não compostas de oito volumes cada uma, sendo quatro volumes do livro do aluno e quatro volumes dos respectivos manuais do professor

Em relação à organização dos conteúdos, é necessário superar o caráter fragmentário das áreas do conhecimento, integrando-as em currículo que possibilite tornar os conhecimentos abordados mais significativos para os educandos e favorecer a participação ativa de alunos com habilidades, experiências de vida e interesses muito diferentes.

A avaliação das obras didáticas submetidas à inscrição no PNLD 2013 busca garantir a qualidade do material a ser encaminhado à escola, incentivando a produção de materiais cada vez mais adequados às necessidades da educação pública brasileira e às diretrizes e orientações aqui indicadas.

Para alcançar esses objetivos, o livro didático deve veicular informação correta, precisa, adequada e atualizada, procurando assegurar que os componentes curriculares e as áreas de conhecimento articulem seus conteúdos, a partir da abordagem de temas abrangentes e contemporâneos, que contemplem diferentes dimensões da vida humana, tanto na esfera individual, quanto global, regional e local. Como parte integrante de suas propostas pedagógicas, as coleções e os livros regionais devem colaborar efetivamente para a construção da cidadania. Nessa perspectiva, as obras didáticas devem representar a sociedade, buscando:

- promover positivamente a imagem de afro-descendentes e descendentes das etnias indígenas brasileiras, considerando sua participação em diferentes trabalhos, profissões e espaços de poder;

- promover positivamente a cultura afro-brasileira e dos povos indígenas brasileiros, dando visibilidade aos seus valores, tradições, organizações e saberes sociocientíficos, considerando seus direitos e sua participação em diferentes processos históricos que marcaram a construção do Brasil, valorizando o caráter multicultural da nossa sociedade; 
- abordar a temática das relações étnico-raciais, do preconceito, da discriminação racial e da violência correlata, visando à construção de uma sociedade antirracista, solidária, justa e igualitária.

Especificamente com relação aos livros regionais, estes devem atender a demandas de comunidades locais, abordadas de forma inespecífica pelas coleções, marcadas por perspectivas necessariamente gerais. Nesse sentido, o principal objetivo desses livros é o de contemplar, em sua especificidade, a História e a Geografia de uma determinada região, estado ou cidade.

Por fim, a avaliação das obras didáticas submetidas à inscrição no PNLD 2013 atende à política de incentivo à produção e qualificação de materiais didáticos no País. $\mathrm{O}$ PNLD cumpre a função, também, de estimular a discussão e participação de professores na escolha dos materiais didáticos a serem utilizados na escola, concorrendo, desse modo, para o exercício competente de sua profissão.

Espera-se, sobretudo, que o livro didático viabilize o acesso de professores, alunos e famílias a fatos, conceitos, saberes, práticas, valores e possibilidades de compreender, transformar e ampliar o modo de ver e fazer a ciência, a sociedade e a educação. Assim, iniciativas editoriais que associem correção conceitual, adequação de atividades e procedimentos, atualização pedagógica e reflexão sobre as interações entre ciência, tecnologia e sociedade constituem importantes instrumentos de apoio e qualificação do ensino

\subsection{HISTÓRIA \\ PRINCÍPIOS GERAIS}

Como área de conhecimento, a História modificou-se bastante ao longo do Século XX. De resgate dos fatos ocorridos, passou a ser entendida como representação desses fatos, por meio da organização, crítica e interpretação das fontes. Em contrapartida, o conhecimento histórico escolar permanece marcado pelo senso comum sobre a História: a enumeração, a mais exata possível, dos acontecimentos, datas e personagens, centrada na informação e na memorização.

Apesar da pluralidade teórica que caracteriza a área, os profissionais da História veem como urgente e necessária a desconstrução desse senso comum, que concebe o livro didático como veiculador de uma verdade absoluta, repositório de toda a informação sobre o passado, informação essa que deve ser prontamente memorizada pelos educandos. Essa representação está relacionada à ideia de ensino-aprendizagem como transmissão de conteúdos apartados do 
cotidiano dos alunos, dificultando, assim, a compreensão das diferenças existentes entre História como área de conhecimento e a História como vivência.

É fundamental a diferenciação entre a vivência desses processos e a forma de produção de conhecimento sobre eles, ou seja, a compreensão do processo histórico e da produção de conhecimento sobre o mesmo. Da capacidade de perceber claramente essas duas dimensões da História dependerá o reconhecimento do valor do conhecimento histórico como base para a compreensão do passado e dos modos humanos padronizados de agir, pensar e sentir, estabelecidos em diferentes tempos e espaços. Viabilizar o pensar historicamente é o objetivo central do ensino-aprendizagem de História e é por meio desse processo que são desenvolvidas as capacidades que auxiliam o aluno a atuar na sociedade de forma autônoma, crítica, participativa, digna e responsável.

Portanto, ensina-se História como se produz o conhecimento histórico, ou seja, tendo a pesquisa como princípio norteador. O desafio de uma coleção didática não é explorar a maior quantidade de conteúdos conceituais. Boa é a obra didática que auxilia o professor e o aluno no trabalho com a metodologia da produção do conhecimento histórico, sempre adequada ao nível de escolaridade a que se destina a coleção.

No caso dos anos iniciais do ensino fundamental e considerando as recomendações do Parecer CNE/CEB 11/2010, a introdução, desenvolvimento e consolidação do processo de aquisição da leitura e da escrita deve se dar pelo acesso do educando à diversidade de gêneros textuais, que servem como suportes de informações de diversas áreas do conhecimento humano. Ressalta-se, portanto, a importância do livro didático de História nesse processo que deve ocorrer nos três anos iniciais do ensino fundamental e a necessidade do conhecimento histórico na formação do cidadão.

Tal ensino deve ser de qualidade, ou seja, deve adequar-se às necessidades socioculturais da sociedade brasileira, considerar os saberes prévios, os interesses, e as potencialidades cognitivas dos alunos. Deve levar em conta os saberes gestados na prática docente e oferecer tecnologia educacional compatível, seja com a legislação educacional em vigor, seja com as tendências científicas abonadas pela academia.

Nesse segmento de ensino fundamental, o livro didático deve, também, contribuir para o desenvolvimento dos conceitos de História (escrita e vivida), fonte, memória, acontecimento, seqüência, encadeamento, períodos, fato, tempo, simultaneidade, ritmos de tempo, medidas de tempo, duração, sujeito histórico, espaço, escala, historicidade, identidade, 
semelhança, diferença, contradição, continuidade, permanência, mudança, causa, ficção, narrativa, verdade, ruptura, explicação e interpretação.

\section{CRITÉRIOS ELIMINATÓRIOS ESPECÍFICOS}

Além dos critérios eliminatórios comuns, para o componente curricular História será observado se a obra didática:

1. Utiliza a intensa produção de conhecimento nas áreas da História e da Pedagogia, realizada nos últimos anos, considerando-a como ponto de reflexão e de discussão;

2. Compreende a escrita da História como um processo social e cientificamente produzido e que desempenha funções identitária e de orientação na sociedade;

3. Explicita as opções teórico-metodológicas (histórica e pedagógica);

4. Apresenta coerência entre as opções teórico-metodológicas explicitadas e o desenvolvimento dos textos principais, textos complementares, ilustrações e com os objetivos gerais do ensino de História para os anos iniciais do ensino fundamental;

5. Adota opções teórico-metodológicas que contribuem efetivamente para a consecução dos objetivos da História acadêmica e da disciplina escolar História para os anos iniciais do ensino fundamental;

6. Desperta os alunos para a historicidade das experiências sociais, trabalhando conceitos, habilidades e atitudes, na construção da cidadania;

7. Estimula o convívio social e o reconhecimento da diferença, abordando a diversidade da experiência humana e a pluralidade social, com respeito e interesse;

8. Trabalha os preceitos éticos de forma contextualizada, visto que, desistoricizados, podem resultar em trechos, capítulos ou partes, dissociados da proposta geral da coleção, se transformando, apenas, em ensinamentos morais e cívicos não condizentes, seja com os objetivos do ensino, seja com a produção do conhecimento histórico;

9. Contribui para o desenvolvimento da autonomia de pensamento, o raciocínio crítico e a capacidade de argumentar do aluno;

10. Apresenta ilustrações variadas quanto às possibilidades de significação, como os desenhos, fotografias e reproduções de pinturas;

11. Apresenta ilustrações que exploram as múltiplas funções das imagens, de forma a auxiliar o aprendizado do alfabetismo visual e do ensino de História;

12. Apresenta, de forma contextualizada, propostas e/ou sugestões para que o educando acesse outras fontes de informações (rádio, TV, internet etc); 
13. Apresenta imagens acompanhadas de atividades de leitura e interpretação e de interação, sempre que possível, referenciadas em sua condição de fonte para a produção do conhecimento histórico.

Para que haja coerência com os princípios acima listados, as obras didáticas não devem conter anacronismos e voluntarismos.

$\mathrm{O}$ anacronismo consiste em atribuir razões ou sentimentos gerados no presente aos agentes históricos do passado, interpretando-se, assim, a História em função de critérios inadequados, como se os atuais fossem válidos para todas as épocas. Trata-se, com efeito, de distorção grave, que compromete totalmente a compreensão do processo histórico.

O voluntarismo, por sua vez, consiste em aplicar a documentos e textos uma teoria $a$ priori, em função do que se quer demonstrar. Dessa forma, a escrita da História é utilizada apenas para confirmar as explicações já existentes na mente da autoria, que parte de convicções estabelecidas por motivos ideológicos, religiosos ou pseudocientíficos. Pode, ainda, originar-se da tentativa da aplicação de teorias explicativas, tomadas acriticamente.

Serão excluídas as obras didáticas que apresentarem erros de informação tópica, nominal ou cronológica.

\section{LIVROS REGIONAIS:}

Os livros denominados regionais são impressos que registram a experiência de grupos que se identificam por fronteiras espaciais e socioculturais, seja na dimensão de uma cidade, um estado ou uma região do Brasil e que são utilizados em situação didática no ensino de história. A produção de tais livros deve respeitar os mesmos critérios acima relacionados e, também, não podem, em nenhuma hipótese, incorrer nos seguintes equívocos:

1. Não explicitar os conceitos de local e/ou região empregados na obra;

2. Interpretar a realidade regional de forma estereotipada, classificando identidades locais como superiores ou inferiores, veiculando regionalismos xenófobos e estimulando o conflito entre formações sociais que tiveram trajetórias marcadamente diferenciadas;

3. Abordar a experiência regional isoladamente, sem levar em conta as suas interrelações com processos históricos em macroescala, na longa duração, ocorridos para além das fronteiras regionais;

4. Abordar a experiência local, apenas, como repetição abreviada de processos históricos em macroescala, ocorridos para além das fronteiras regionais; 
5. Abordar a experiência local, apenas, em seus traços pitorescos e anedóticos, assemelhando o livro didático a um roteiro para a visitação turística. 